\title{
MPRA
}

Munich Personal RePEc Archive

\section{On the Use of Palynological Data in Economic History: New Methods and an Application to Agricultural Output in Central Europe, 0-2000 AD}

Izdebski, Adam and Koloch, Grzegorz and Słoczyński, Tymon and Tycner-Wolicka, Marta

March 2014

Online at https://mpra.ub.uni-muenchen.de/54582/

MPRA Paper No. 54582, posted 23 Mar 2014 14:51 UTC 


\title{
On the Use of Palynological Data
}

\author{
in ECONOMic History: New Methods
}

\author{
And An Applichtion to Agricultural
}

Output in Central Europe, 0-2000 AD*

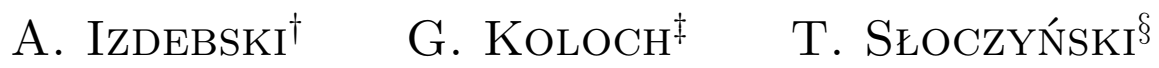 \\ M. TYCNER-WOLICKA
}

Abstract: In this paper we introduce a new source of data to economic history: palynological data, i.e. information about pollen grains which are preserved in bottom sediments of various water basins. We discuss how this data is collected and how it should be interpreted; develop new methods for aggregating this information into regional trends in agricultural output; construct an extensive data set with a large number of pollen sites from Central Europe; and use our methods to study the economic history of Greater Poland, Lesser Poland, Bohemia, Brandenburg, and Lower Saxony since the first century AD.

${ }^{*}$ This project was funded by the Ministry of Research and Higher Education of the Republic of Poland within the Iuventus Plus program (grant IP2011 018371). The project was based at and administered by the Institute of History of the Polish Academy of Sciences. Tymon Słoczyński also acknowledges a START scholarship from the Foundation for Polish Science (FNP). We benefited from comments and discussions with participants in the ESEH Conference (Munich), the FRESH Meeting (Warsaw), the World Economic History Congress (Stellenbosch), and seminars at the Jagiellonian University in Krakow, the Polish Academy of Arts and Sciences (PAU), the Polish Academy of Sciences (PAN), and the University of Warsaw. We are also grateful to Piotr Kołaczek, Radka Kozáková, and Petr Pokorný who generously provided the data which is not available in the European Pollen Database. We thank Jesse Simon for improving the language style.

${ }^{\dagger}$ Jagiellonian University in Krakow.

${ }^{\ddagger}$ Warsaw School of Economics.

$\S$ Michigan State University; Warsaw School of Economics; and IZA, Bonn.

IUniversity of Oxford. 


\section{Introduction}

Economic historians are often interested in studying the dynamics of human activity over the very long term. ${ }^{1}$ However, data about the past is inherently scarce, and many interesting questions, especially about the pre-modern era, cannot be answered. As noted by Steckel (2013), "economic historians are left with surviving scraps of evidence, often collected for other purposes"; they "cannot design or update a survey to gather more information"; they "cannot interview the deceased"; and they "are stuck with what was recorded, has survived, and is now housed in an accessible location". As a consequence, various researchers aim to collect and analyze data from non-standard sources which could serve as a proxy for human activity. For example, skeletal remains are now routinely used as a source of data about the evolution of human health (Steckel, 2003; Koepke and Baten, 2005, 2008; Steckel, 2008, 2013). Other "biological measures of economic history", namely mortality rates, stature, and body mass index (BMI), are also used to study shorter time periods. ${ }^{2}$

In this paper we introduce palynological data as an alternative "biological measure" which can also serve as a useful proxy for human activity. Various plants produce pollen grains and spores which are then accumulated in the bottom sediments of lakes and other water basins. Palynologists extract sediment cores from the floor of lakes, establish a chronology of layers of sediments, and count pollen grains of various plant taxa within each layer. Selected taxa - especially Cerealia (cereals) - are generally regarded as anthropogenic indicators, and variations in their relative presence can be interpreted as variations in human activity (Behre, 1981; Feeser and Furholt, 2013). However, most of the palynological literature focuses on local phenomena (a single site or several sites in close proximity to one another) which are arguably of

\footnotetext{
${ }^{1}$ Similar questions are also of interest to growth theorists. For example, Galor and Weil (2000) and Galor and Moav (2002) develop a unified growth theory which is intended to capture varying patterns of stagnation and growth over the entire course of human history. Related contributions include Goodfriend and McDermott (1995), Acemoglu and Zilibotti (1997), Kelly (2001), Kögel and Prskawetz (2001), Hansen and Prescott (2002), and Lagerlöf (2003).

${ }^{2}$ See, e.g., Voth and Leunig (1996), Baten and Murray (2000), Komlos et al. (2003), Komlos (2007), Baten et al. (2010), Brainerd (2010), and Austin et al. (2012) for recent applications.
} 
limited interest to economic historians. ${ }^{3}$ Therefore, we must develop new methods of aggregating palynological data into regional trends. Our methods take into account both the geographical distribution of pollen sites and the chronological distributions of core samples which can (and do) differ between these sites. Moreover, we use cross validation to determine the optimal structure of penalties for spatial distance and time distance. We then use our methods to study long-term variation in agricultural output in Central Europe during the last two millennia.

Our paper is thereby related to an important field of research in economic history which studies trends in agricultural production and productivity. Notable contributions to this field include Clark (1991), O'Brien and Prados de la Escosura (1992), Allen (2000), Olmstead and Rhode (2002), Federico and Malanima (2004), Allen (2009), Campbell and Ó Gráda (2011), Kelly and Ó Gráda (2013), and many others. The advantage of our approach is that it significantly extends the timespan of analysis. While most of these previous studies are restricted to several centuries or less, our paper investigates regional trends in agricultural output in Greater Poland, Lesser Poland, Bohemia, Brandenburg, and Lower Saxony since the first century AD. The disadvantage of our data, however, is that it cannot be transformed into common measures of amount of land under cultivation and output per unit of land. On the contrary, this data is inherently relative, and is only suggestive of the relative importance of various plant taxa in the vegetation of a given region. Clearly, each source of data has its own limitations; our intention is therefore to increase the number of alternative sources which are available to economic historians.

The remainder of this paper is organized as follows. In the next section, we provide a short introduction to palynology, and discuss how palynological data is collected and how it should be interpreted. In Section 3, we develop new methods of aggregating

\footnotetext{
${ }^{3}$ To the best of our knowledge, there exists only one paper in the economic literature which analyzes palynological data. Namely, Hanley et al. (2009) study economic determinants of long-run biodiversity change, and they use pollen data to construct their measure of diversity. Therefore, they do not use pollen data to approximate actual human activity, while this is the approach which we take in this paper.
} 
such data into regional trends. In Section 4, we describe our data set. In Section 5, we use our methods to analyze this data as well as discuss our findings. Finally, in Section 6, we offer some conclusions from our research.

\section{Background}

Nature has its own archive, in which information from its past is stored in the form of sediment which accumulates over millennia. Among these archives, lakes and marshes preserve material from the most recent periods. In particular, lakebed and peat sediments, accumulated every year, contain pollen grains produced by the surrounding vegetation. This pollen signal reflects the spatial structure of vegetation around a lake or marsh in a given period, and the radius which delineates the relevant area can vary from less than one kilometer to dozens of kilometers, depending on the plant in question (Sugita, 1993; Gaillard et al., 2008; Hellman et al., 2009). The task of palynology is to retrieve and analyze this material, so that one can reconstruct the past environment around a given site. ${ }^{4}$

The first step is to extract a core sample from a lakebed or peat accumulation. Sediment cores of an appropriate length (often several meters) are brought to laboratories, where pollen samples for microscope analyses, and organic material for radiocarbon dating, are collected at regular intervals (usually a few centimeters). Then, pollen grains from each sample are identified and counted, and this procedure results in creation of a data set with counts of pollen grains from different plants or plant groups. Each of these plants or plant groups is typically referred to as taxon (pl. taxa), since for some plants it is possible to identify the exact species while, in other cases, only a genus or family can be identified. Palynologists never count all the pollen grains in a sample, and usually restrict their attention to a subsample of 500-1,500 grains which is believed to provide representative information on the

\footnotetext{
${ }^{4} \mathrm{~A}$ good introduction to palynology for historians is provided by Eastwood (2005). See also methodological discussions in Vermoere (2004) and Izdebski (2013).
} 
proportions of pollen grains in a sample.

Such a data set has only an ordinal chronology which is based on the actual core depths of subsequent samples. However, there are several methods of constructing an absolute chronology for this data. Typically, radiocarbon dating is applied to organic material from a selection of core depths. Once these dates are known, it is possible to model the relationship between age and depth in a particular core and to extrapolate ages on depths for which there is no radiocarbon date, while taking into account the geological structure of the core (Björck and Wohlfarth, 2001). The changing relationship between depth and age is described by the accumulation rate, i.e. the amount of sediment that accumulates every year, and this value is almost never stable throughout the history of a core. The modeling also involves a transformation of original radiocarbon dates into calibrated ones (Reimer et al., 2009), and the final result is an estimate of a calendar year for each sample.

The resulting data set contains information about pollen counts of various plant taxa in different years, and these dates are usually distributed in an irregular way, because sampling and laboratory analysis are never rigorously regular, and the accumulation rate also tends to vary over time. Importantly, pollen counts only become meaningful after their recalculation into their proportion in the pollen sum, i.e. the number of all pollen grains in a sample. Consequently, every interpretation of pollen profiles is concerned with the changing structure of the pollen signal which is informative about the structure of the vegetation around a given site. Recent research has examined the possibility of translating the changing proportions of plant taxa into exact measures of land cover (Gaillard et al., 2008; Hellman et al., 2008; Fyfe et al., 2010), although such inferences are typically regarded as too extreme. Of course, this does not mean that the changing proportions of plant pollen in sediment cores do not reflect the transformations of land cover - on the contrary, recent studies on contemporary pollen dispersal confirm that this information is contained in the pollen signal (Andrade et al., 1994; Díaz, 1994; Vermoere et al., 2001; Favre et al., 2008). 
Thus, at present, any interpretation should focus on the changes in proportion of those pollen grains which represent the plant taxa of interest, when and how quickly they increase or decrease, and how long they remain stable. Moreover, interpretations of pollen profiles require considerable knowledge of how different plants produce pollen and how it is distributed, as well as the ecological 'habits' of these plants, in particular their relationship with human activity (Behre, 1981). In this paper, because of our interest in agricultural output, we focus solely on cereals, and examine how their share in the vegetation of entire regions has changed since the beginning of the European Middle Ages. From this period onward, cereals are certainly the clearest and most reliable indicator of human activity in the landscape, together with forest clearance and pasturing. However, while these two phenomena are visible in pollen profiles, their interpretation is much more complex and less certain, as they would, with the exception of very specific cases, normally appear in conjunction with cereal cultivation. In consequence, we focus on pollen grains which represent wheat, rye, barley, oats, and a separate category of Cerealia-type, i.e. those pollen grains that certainly belong to cereals, but where the state of preservation does not allow for attribution to any specific species. Importantly, we do not consider millet, since its pollen is undistinguishable from pollen of other plants of the genus of Panicum.

\section{Method}

\subsection{Framework and Notation}

Let there be $m$ sites, indexed by $k=1,2, \ldots, m$, and $n$ plant taxa, indexed by $j=1,2, \ldots, n$. Also, let $\Omega=\{1,2, \ldots, m\}$. Each site $k \in \Omega$ is represented by: (i) A series of time periods $T_{k}=\left(t_{k_{1}}, t_{k_{2}}, \ldots, t_{k_{n_{k}}}\right)$ which represent dates on which measurements were carried out at site $k$. Series $T_{k}$ consists of $n_{k} \geqslant 1$ elements which can vary across $k$. Moreover, measurement dates do not have to overlap across sites.

(ii) A matrix of measurements $Z_{k}$ where $z_{k}(i, j)$, the $(i, j)$-th element of $Z_{k}$, is equal 
to the fraction of $j$-type pollen grains in the overall number of pollen grains at site $k$, as measured on date $T_{k}(i)$. (iii) A pair of coordinates $c_{k}=\left(x_{k}, y_{k}\right)$ which represent the geographical location of site $k$. (iv) A quality index $q_{k} \in[0,1]$ which represents the quality of measurements at site $k$.

Also, let there be $w$ regions and let the $q$-th region include $\omega_{q} \subset \Omega$, a subset of available sites. Let $T=\left(T_{\min }, T_{\min }+1, T_{\min }+2, \ldots, T_{\max }\right)$ and $i=1,2, \ldots, T_{\max }-$ $T_{\text {min }}+1$. Series $T$ represents our time periods of inference which are common for all sites. Define our goal to be the construction of matrices $X_{q}, q=1,2, \ldots, w$, such that $x_{q}(i, j)$ is an estimate of the fraction of $j$-type pollen grains in the overall number of pollen grains in region $\omega_{q}$, as measured on date $T(i)$.

Our procedure now consists of three steps: interpolation, smoothing, and aggregation. In the first step, for each site $k$, we interpolate missing measurements in $Z_{k}$. Let $\bar{T}_{k}=\left[T_{k}(1), T_{k}(1)+1, T_{k}(1)+2, \ldots, T_{k}\left(n_{k}\right)\right]$ where $n_{k}$ is the number of measurements which are available at site $k$. Then, missing measurements correspond to time periods $\bar{T}_{k} \backslash T_{k}$, and we interpolate them, for each site $k$ and each taxon $j$, using a linear spline function with data points located in $\left(T_{k}(i), z_{k}(i, j)\right), i=1,2, \ldots, n_{k}$. Therefore, in this step, for each site $k$, we obtain measurements for all $t \in \bar{T}_{k}$. Let these measurements be collected in matrices $\bar{Z}_{k}=\left[\bar{z}_{k}(i, j), i=1,2, \ldots, \bar{n}_{k}, j=1,2, \ldots, n\right]$ where $\bar{n}_{k}=T_{k}\left(n_{k}\right)-T_{k}(1)+1$.

In the second step, measurements in $\bar{z}_{k}(j)=\left(\bar{z}_{k}(1, j), \bar{z}_{k}(2, j), \ldots, \bar{z}_{k}\left(\bar{n}_{k}, j\right)\right)^{T}$ are smoothed using a low-pass filter, i.e. a filter which erases high-frequency fluctuations from the time series, as they can be attributed to random noise and errors in physical measurement. We smooth independently across $k$ and $j$, i.e. across sites and taxa, in order to obtain the smoothed measurement series, $\check{z}_{k}(j)$. More specifically, we use the Hodrick-Prescott filter, which sets $\check{z}_{k}(j)$ as a minimizer of the following function (Hodrick and Prescott, 1997):

$$
\sum_{i=1}^{\bar{n}_{k}}\left(\bar{z}_{k}(i, j)-\check{z}_{k}(i, j)\right)^{2}+\lambda \sum_{i=2}^{\bar{n}_{k}-1}\left(\check{z}_{k}(i-1, j)+\check{z}_{k}(i+1, j)\right)^{2}
$$


where $\lambda$ is a free parameter. If any measurement becomes negative after the smoothing, it is replaced by zero. Vectors $\check{z}_{k}(j)$, for $j=1,2, \ldots, n$, constitute a matrix of interpolated and smoothed measurements at site $k$, and we denote it by $\check{Z}_{k}=\left[\check{z}_{k}(i, j)\right]$.

After interpolation and smoothing, vectors $\check{z}_{k}(j)$ are of the same length when $k$ is fixed, but they can vary in this respect when $k$ changes. In particular, they do not necessarily contain the entire time range $T$, for which aggregation is to be done.

Therefore, let $T_{k}^{\star}=T \cap \bar{T}_{k}$ and let $Z_{k}^{\star}$ be composed of those rows of $\check{Z}_{k}$ which correspond to time periods in $T_{k}^{\star}$. Let $z_{k}^{\star}(j)$ denote the $j$-th column of $Z_{k}^{\star}$ and let $n_{k}^{\star}$ denote the length of $z_{k}^{\star}(j)$ which is equal across $j$. For site $k$, missing measurements in vectors $\breve{z}_{k}(j), j=1,2, \ldots, n$, correspond to time periods $\breve{T}_{k}=T \backslash T_{k}^{\star}$. If $T_{\min } \in \breve{T}_{k}$, then we use $\check{z}_{k}(1, j)$ to replace measurements in time periods $T_{\min }, T_{\min }+1, \ldots, T_{k}^{\star}(1)-$

1 (for each $j=1,2, \ldots, n$ ). Analogously, if $T_{\max } \in \breve{T}_{k}$, then we use $\check{z}_{k}\left(\bar{n}_{k}, j\right)$ to replace measurements in time periods $T_{k}^{\star}\left(n_{k}^{\star}\right)+1, T_{k}^{\star}\left(n_{k}^{\star}\right)+2, \ldots, T_{\max }$ (for each $j=$ $1,2, \ldots, n$ ). Let the resulting measurement matrix be denoted by $\tilde{Z}_{k}$ (which is $|T| \times n$ for each $k$, where $\left.|T|=T_{\max }-T_{\min }+1\right)$.

In the third step, for each region $\omega_{q}$, these measurements are aggregated into regional trends. We develop three aggregation methods which we describe in subsequent subsections. These methods differ in the degree to which they incorporate additional spatial and time information which is entirely omitted by the simplest approach.

\subsection{Simple Aggregation}

Let $x_{q}(j)$ denote the $j$-th column of $X_{q}$. For each region $\omega_{q}$, vectors $x_{q}(j), j=$ $1,2, \ldots, n$, are constructed according to the following procedure:

$$
x_{q}(j)=\frac{1}{\sum_{k \in \omega_{q}} q_{k}} \sum_{k \in \omega_{q}} \tilde{z}_{k}(j) \cdot q_{k}
$$




\subsection{Incorporating Spatial Information}

In the previous subsection, for each region $\omega_{q}$, there is a single matrix $X_{q}$ which is assumed to represent inferred pollen fractions for various plant taxa in the region as a whole. Now we want to relax this assumption and utilize spatial information which is contained in pairs of coordinates of respective sites. In particular, we assume that information which is relevant for inference at any given location is a function of the distance between this location and the pollen site, from which the information originates. A similar approach is typical for gravity models of trade in economics where the intensity of trade between two countries varies inversely with the distance between them (Anderson, 1979; Anderson and van Wincoop, 2003).

Such an extension allows for inference at any location which is described by a pair of coordinates $(x, y)$, so that the matrix $X_{q}$ is a function of these coordinates, $X_{q}=X_{q}(x, y)$. In particular, we can define a set of pairs of coordinates $\mathcal{C}_{q}$ which defines $q$ in a spatial sense. Then, for each region $\omega_{q}$, we can construct a spatial $\operatorname{map}\left\{X_{q}(x, y):(x, y) \in \mathcal{C}_{q}\right\}$ of this region. Such a map not only describes how the distribution of pollen fractions for various plant taxa changes over time, but also how these fractions are distributed spatially across the region $\omega_{q}$ for a given $t \in T .^{5}$

In our applications we restrict our attention to describing each region $\omega_{q}$ by a single pair of coordinates, $\mathcal{C}_{q}=\left\{\left(x_{q}, y_{q}\right)\right\}$, and we assume these coordinates to be representative for $q$. Then, $X_{q}=X_{q}\left(x_{q}, y_{q}\right)$ represents, as before, pollen fractions for various plant taxa in region $\omega_{q}$. In particular, we first describe each region $\omega_{q}$ by a set of four vertices, $\Theta_{q}=\left\{\left(x_{q r}, y_{q r}\right), r=1,2,3,4\right\}$, i.e. we define $q$ to be a quadrangle. Then, we assume that coordinates $\left(x_{q}, y_{q}\right)$, which ultimately represent region $\omega_{q}$, are given by geometric centers of the quadrangle $\Theta_{q}$, namely we assign the same mass to

\footnotetext{
${ }^{5}$ Note that our concept of spatial maps is very closely related to isopollen maps in palynology. See, e.g., Webb (1974), Ralska-Jasiewiczowa (1983), Ralska-Jasiewiczowa et al. (2004), and Feeser and Furholt (2013).
} 
each vertex $\left(x_{q r}, y_{q r}\right) \in \Theta_{q}$ :

$$
\left(x_{q}, y_{q}\right)=\frac{1}{4} \sum_{\left(x_{q r}, y_{q r}\right) \in \Theta_{q}}\left(x_{q r}, y_{q r}\right)
$$

Let $x_{q}(j)$, as previously, denote the $j$-th column of $X_{q}$. For each region $\omega_{q}$, vectors $x_{q}(j), j=1,2, \ldots, n$, are constructed according to the following procedure:

$$
x_{q}(j)=\sum_{k \in \omega_{q}} \tilde{z}_{k}(j) \cdot w_{k}
$$

where weights $w_{k}$ sum to one, are corrected with quality indexes $q_{k}$, and contain spatial information such that, controlling for quality, i.e. for $q_{k}, w_{k} \propto \rho_{q, k}^{-\alpha}$ where $\rho_{q, k}$ is the Euclidean distance between location of region $\omega_{q}$, which is given by $\left(x_{q}, y_{q}\right)$, and of site $k$, which is given by its spatial coordinates. Note that $\alpha \geqslant 0$ is a free parameter. If $\alpha=0$, then the current procedure is equivalent to the previous one.

\subsection{Incorporating Spatial and Time Information}

In this subsection we extend the spatial approach so that it also takes into account the fact that time periods for which measurements are available at site $k$, i.e. time periods in $T_{k}$, neither overlap across the sites (i.e. across $k$ ), nor are uniformly distributed over the time span $\left[T_{k}(1), T_{k}\left(n_{k}\right)\right]$. Moreover, their intersection with $T$ can be arbitrary. As a consequence, when inference about $x_{q}(i, j)$ is made for a given region $\omega_{q}$ on the basis of measurements in $\tilde{z}_{k}(i, j), k \in \omega_{q}$, some of the information from these measurements is more relevant than the other, depending on the time distance of $T(i)$ from measurements which are closest to $T(i)$ in $T_{k}, k \in \omega_{q}$. Therefore, analogically to the spatial case, here we use a notion of time distance, $\psi_{i, k}$, where:

$$
\psi_{i, k}=\min _{\tau \in T_{k}}|T(i)-\tau|
$$


is equal to the minimal number of years between $T(i)$ and $T_{k}$, i.e. between the date in which $x_{q}(i, j)$ is to be estimated and any date in which some measurement was originally available for site $k$. For each region $\omega_{q}$, elements $x_{q}(i, j)$ of vectors $x_{q}(j)$, $j=1,2, \ldots, n$, are constructed according to the following procedure:

$$
x_{q}(i, j)=\sum_{k \in \omega_{q}} \tilde{z}_{k}(i, j) \cdot w_{i, k}
$$

where weights $w_{i, k}$ sum to one, are corrected with quality indexes $q_{k}$, and contain spatial information such that, controlling for quality and time distance, $w_{i, k} \propto \rho_{q, k}^{-\alpha}$ as well as, controlling for quality and spatial distance, $w_{i, k} \propto \psi_{i, k}^{-\beta}$ where $\alpha \geqslant 0$ and $\beta \geqslant 0$ are free parameters. More specifically, we assume that:

$$
w_{i, k} \propto(1-\theta) \cdot \rho_{q, k}^{-\alpha}+\theta \cdot \psi_{i, k}^{-\beta}
$$

where $\theta \in[0,1]$ is a free parameter.

Also, note that the current procedure is equivalent to the previous one if $\theta=0$. On the other hand, if $\theta=1$, then spatial information is neglected and we only use information about time distances. The latter approach, however, seems less appealing a priori, since the purpose of using the information on time differences between various measurements is only to adjust spatial relations for the fact that information in respective measurements is more or less outdated from the perspective of $T(i)$.

\subsection{Cross Validation}

Parameters $\alpha, \beta$, and $\theta$ are arbitrary and their proper selection constitutes a problem of model calibration. We use cross validation to select these parameters, so that they minimize in-sample prediction errors for available data points. This subsection describes our calibration strategy.

For each site $k$, we have appropriate measurements in $\tilde{Z}_{k}$. We analyze, one by one, all sites which are available, $k \in \Omega$, and we use our methods to predict corresponding 
measurements, at each $k$, using all the information in $\omega_{q} \backslash\{k\}$. Then, we compare these predicted values, $X_{k}$, with actual ones, $\tilde{Z}_{k}$. The error matrix, $\Gamma_{k}=X_{k}-\tilde{Z}_{k}$, produces the root-mean-square error (RMSE) of prediction:

$$
\mu_{k}=\operatorname{tr}\left(\frac{1}{|T| \cdot n} \Gamma_{k}^{T} \Gamma_{k}\right)^{\frac{1}{2}}
$$

where $|T|=T_{\max }-T_{\min }+1$ and $\operatorname{tr}$ is a trace operator. We obtain $\mu_{k}$ for each $k$ and compute the resulting total RMSE:

$$
\mu=\frac{1}{m} \sum_{k \in \Omega} \mu_{k}
$$

Note that $\mu=\mu(\alpha, \beta, \theta)$, i.e. the total RMSE, is a function of $\alpha, \beta$, and $\theta$. In consequence, we minimize the total RMSE over these parameters. ${ }^{6}$

\section{Data}

In this section we describe our data set, which contains all pollen sites from Central Europe with reliable information on human activity in the last two millennia. We have used two criteria for including pollen sites to this data set: (i) that a given site provides data for cereals; and (ii) that the chronology of the last two millennia can be based on varve years or radiocarbon dating. In most cases, we have retrieved these data either from the European Pollen Database (Fyfe et al., 2009) or from the PALYCZ database (Kuneš et al., 2009) which gathers information on pollen sites in the Czech Republic and Slovakia. ${ }^{7}$ The resulting data set consists of 36 pollen sites which we group in five regions (see Table 1).

Clearly, it is essential to ensure the chronological reliability of such data. To accomplish this goal, instead of relying on the original age-depth models for our pollen

\footnotetext{
${ }^{6}$ We use a grid search and consider the following values for the respective three parameters: $\alpha=0,0.25,0.5, \ldots, 3.75,4 ; \beta=0,0.25,0.5, \ldots, 3.75,4$; and $\theta=0,0.125,0.25, \ldots, 0.875,1$.

${ }^{7}$ See also http://www.europeanpollendatabase.net/ and http://botany.natur.cuni.cz/ palycz/, respectively (accessed March 15, 2014).
} 
Table 1: Pollen Sites

\begin{tabular}{|c|c|c|c|c|c|}
\hline & Site name & Latitude & Longitude & Chronological quality & Original publication \\
\hline \multicolumn{6}{|c|}{ A - Greater Poland } \\
\hline 2. & Lake Skrzetuszewskie 1 & 52.55000 & 17.36056 & 2 & Tobolski (1991) \\
\hline 3. & Lake Skrzetuszewskie 2 & 52.55000 & 17.36056 & 1 & Tobolski (1990) \\
\hline 4. & Lake Lednica & 52.55694 & 17.39028 & 2 & Makohonienko (1991) \\
\hline 6. & Sławsko & 52.66667 & 18.25000 & 3 & Unpublished \\
\hline 7. & Lake Gościąż & 52.58333 & 19.35000 & 1 & Ralska-Jasiewiczowa et al. (1998) \\
\hline \multicolumn{6}{|c|}{ B - Lesser Poland } \\
\hline 8. & Zlatnická Dolina & 49.51667 & 19.28333 & 1 & Rybníček and Rybníčková (1985) \\
\hline 12. & Regetovka & 49.42500 & 21.27917 & 1 & Wacnik (1995) \\
\hline 13. & Cergowa Góra & 49.53333 & 21.70000 & 1 & Szczepanek (2001) \\
\hline 14. & Jasiel & 49.37278 & 21.88694 & 2 & Szczepanek (1987) \\
\hline 15. & Tarnawa Wyżna 1 & 49.10000 & 22.83333 & 2 & Ralska-Jasiewiczowa (1980) \\
\hline \multicolumn{6}{|c|}{$\mathrm{C}$ - Bohemia } \\
\hline 16. & Na bahně & 50.19888 & 15.96119 & 1 & Pokorný et al. (2000) \\
\hline 17. & Stará Boleslav (hradiště) & 50.19793 & 14.66743 & 3 & Unpublished \\
\hline 18. & Stará Boleslav (čistička) & 50.19793 & 14.66743 & 1 & Břízová (1999) \\
\hline 19. & Brve & 50.07178 & 14.24492 & 1 & Pokorný and van der Knaap (2011) \\
\hline 24. & Großer Treppelsee & 52.15000 & 14.45278 & 1 & Giesecke (2000) \\
\hline 25. & Langes Fenn Kemnitzerheide & 52.31361 & 12.91361 & 1 & Wolters (1999) \\
\hline 26. & Großer Krebssee 1 & 52.84659 & 14.09932 & 2 & Jahns (1999b, 2000) \\
\hline 27. & Großer Krebssee 2 & 52.84659 & 14.09932 & 3 & Jahns (1999b, 2000) \\
\hline 28. & Felchowsee 1 & 53.05509 & 14.12928 & 3 & Jahns (2000) \\
\hline 29. & Löddigsee & 53.43333 & 11.85000 & 1 & Jahns (2007) \\
\hline \multicolumn{6}{|c|}{ E - Lower Saxony } \\
\hline 30. & Ahlequellmoor & 51.73056 & 9.50944 & 1 & Jahns (2006) \\
\hline 31. & Silberhohl & 51.91023 & 10.18267 & 2 & Chen (1988) \\
\hline 32. & Burchberg 2 & 51.75902 & 10.46010 & 3 & Willutzki (1962) \\
\hline 33. & Wachel 3 & 53.43889 & 8.86889 & 3 & Dörfler (1989) \\
\hline 34. & Waschhorn & 53.61500 & 8.73694 & 2 & Kühl (1998) \\
\hline 35. & Flögeln 5 & 53.66667 & 8.76389 & 2 & Behre (1976) \\
\hline 36. & Ahlenmoor & 53.70000 & 8.73333 & 3 & Behre (1976) \\
\hline
\end{tabular}


Figure 1: Pollen Sites and Regions

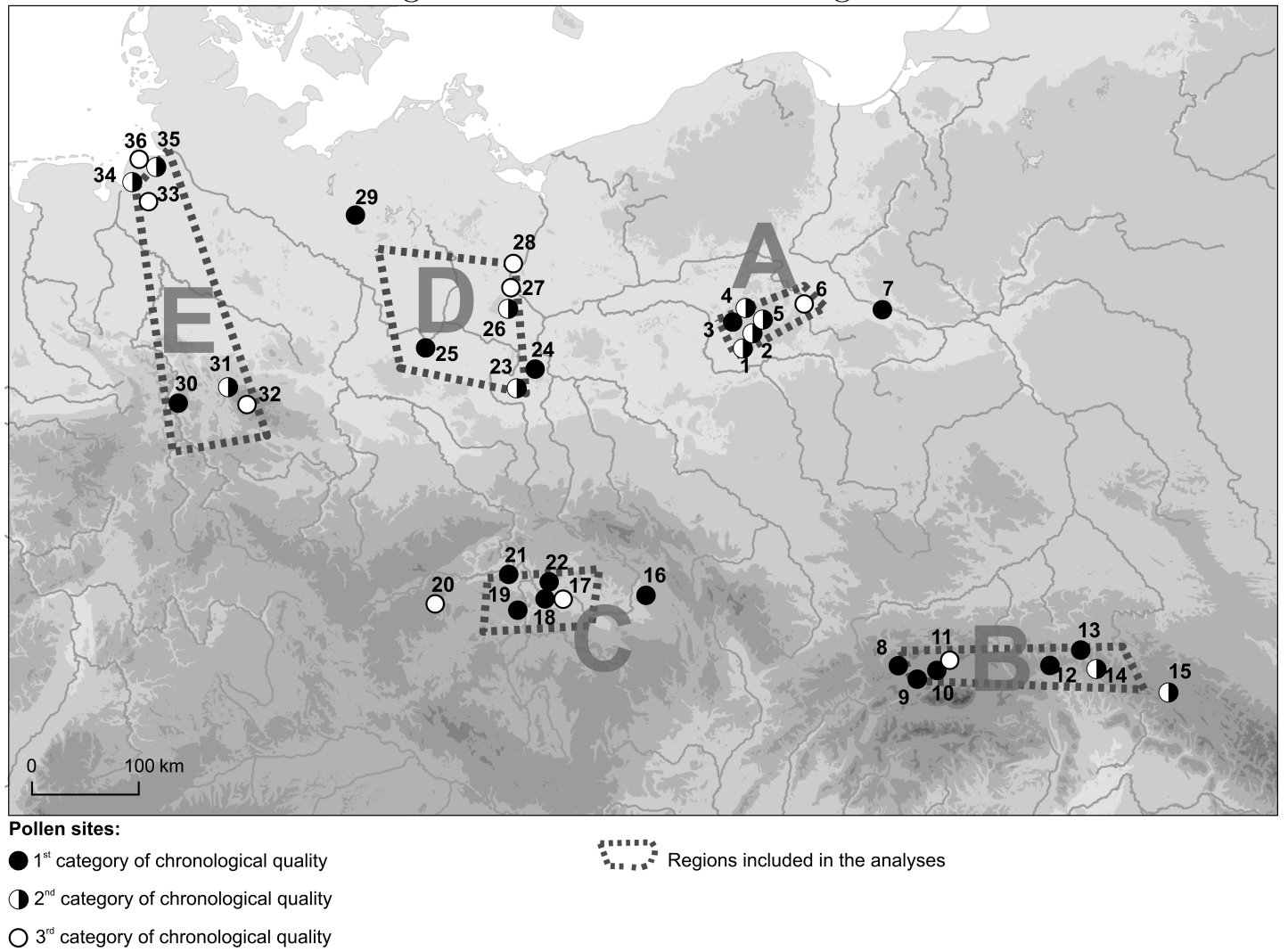

sites, we have produced our own chronological models for 25 out of 36 cases, using a computer program called clam (Blaauw, 2010). ${ }^{8}$ Moreover, we have divided our pollen sites into three categories of chronological quality, and we explicitly utilize this information in our aggregation procedures to reweight these data and ensure thereby a bigger impact of more reliable sites (see Section 3). Namely, we use the following categories and weights: (i) a certain surface date and a minimum of one radiocarbon date for the last millennium and a minimum of one additional radiocarbon date, or varve chronology (1st category, weight: 1.00); (ii) a certain surface date and either lack of radiocarbon dates for the last millennium or only one radiocarbon date in total (2nd category, weight: 0.90); and (iii) an uncertain surface date (3rd category, weight: 0.70$){ }^{9}$

\footnotetext{
${ }^{8}$ See also http://chrono.qub.ac.uk/blaauw/clam.html (accessed March 15, 2014). Note that we provide further details on these new age-depth models in our companion paper (Izdebski et al., 2014).

${ }^{9}$ Note that all of our main results are robust to not using these weights, and instead attaching the same weight to each site.
} 
Table 2: Regions

\begin{tabular}{cccccccc}
\hline \hline & Region & Number of samples & & Vertex 1 & Vertex 2 & Vertex 3 & Vertex 4 \\
\hline \multirow{2}{*}{$\mathrm{A}$} & Greater Poland & \multirow{2}{*}{170} & $\phi$ & 52.241466 & 52.632542 & 52.822268 & 52.563308 \\
& & & $\lambda$ & 17.258778 & 18.547125 & 18.262310 & 17.032557 \\
$\mathrm{~B}$ & \multirow{2}{*}{ Lesser Poland } & \multirow{2}{*}{202} & $\phi$ & 49.643513 & 49.379691 & 49.531448 & 49.145587 \\
& & $\lambda$ & 19.332840 & 19.453640 & 22.256184 & 22.484457 \\
$\mathrm{C}$ & \multirow{2}{*}{ Bohemia } & \multirow{2}{*}{245} & $\phi$ & 50.346775 & 49.884681 & 49.941278 & 50.427987 \\
& & $\lambda$ & 13.836880 & 13.789845 & 15.228367 & 15.337887 \\
$\mathrm{D}$ & \multirow{2}{*}{ Brandenburg } & \multirow{2}{*}{236} & $\phi$ & 53.152947 & 52.136017 & 51.940032 & 53.049469 \\
& \multirow{2}{*}{$\mathrm{E}$} & \multirow{2}{*}{ Lower Saxony } & $\lambda$ & 12.198143 & 12.569504 & 14.329548 & 14.152908 \\
& & & $\phi$ & 53.545204 & 51.309155 & 51.502118 & 53.896449 \\
& & & $\lambda$ & 8.667412 & 9.485950 & 10.765858 & 9.093533 \\
\hline
\end{tabular}

The Central European regions for which we have conducted our analyses are not those of our choice, but rather they have been determined by the availability of palynological data for Germany, Poland, the Czech Republic, Slovakia, Ukraine, Belarus, Lithuania, Latvia, and Estonia. In our view, it would not be reasonable to conduct aggregations without data for at least 4-5 pollen sites. This rule of thumb has allowed us to identify five clusters of pollen sites, two in Poland, one in the Czech Republic, and two in Germany (see Figure 1 and Table 2). Two of these regions (C and D) can be described as reflecting a coherent historical-geographical region, while others represent only parts of such regions (both regions in Poland, A and B) or are subject to an imbalanced spatial distribution of pollen sites (region E in Germany). Thus, the two clusters of pollen sites in Poland are located in the most important historical regions of the Polish state: Greater (A) and Lesser (B) Poland. The part of Greater Poland covered by our pollen sites is consistent with the area where the Polish state was established in the tenth century and which retained its economic - and, to some extent, political - importance until modern times. On the contrary, the southern areas of Lesser Poland were just a remote hinterland of Krakow and Lesser Poland proper, and it was around Krakow that processes parallel to those in Greater Poland were taking place in the Middle Ages. Region C corresponds entirely to historical Bohemia, the central region around the Czech capital of Prague; on the other hand, region D, which can be identified with Brandenburg, did not play such a central role within the German world. Nevertheless, at the turn of the eleventh 
century, the processes of state formation seem to have started here as well, and - after the integration of the region into the German Reich in the twelfth-thirteenth century - the area demarcated as region D remained a separate entity within the German world, with its own political and cultural history. Finally, region E can be considered to represent modern Lower Saxony, the territories conquered by Charlemagne in the late eighth century which formed a separate and distinct region from the Rhine area to the south-west. In our data set, unfortunately, this region is represented primarily by pollen sites grouped in its northernmost part (in Frisia), with some additional sites in the Harz. Nevertheless, our results for this region are interesting enough to merit their inclusion in our historical interpretations.

\section{Results}

\subsection{Introductory Remarks}

Our historical interpretations are generally based on the most advanced aggregation method, which we describe in Section 3.4. This method takes into account not only the chronological quality of pollen sites and their geographical distribution, but also the chronological distribution of pollen samples in sediment cores. This last aspect is very important with regard to the specificity of our data. Before conducting the aggregation itself, the data is transformed into a time series with non-missing observations for every calendar year. This interpolation results in losing the initial information on time periods for which we have actual observations. By weighting our pollen sites by their time distance from each time period, we attempt to reintroduce this valuable information.

In order to investigate the economic-agrarian histories of particular regions, we present our reconstructions as cumulative diagrams of various types of cereals. In this way, we can show the changing structure of the agricultural output of each region. We need to bear in mind, however, that our data does not contain information 
Table 3: Pollen Productivity of Cereals

\begin{tabular}{ccc}
\hline \hline & $\begin{array}{c}\text { Amount of pollen per stamen } \\
\text { in Uttar Pradesh, India }\end{array}$ & $\begin{array}{c}\text { Amount of pollen per stamen } \\
\text { in Germany/Poland }\end{array}$ \\
\hline Rye & 13,200 & $19,000 / 22,360$ \\
Wheat & 2,910 & \\
Oats & 2,300 & \\
Barley & 2,410 & \\
\hline
\end{tabular}

NOTE: For Uttar Pradesh, see Agnihotri and Singh (1975); for Germany, see Pohl (1937); for Poland, see Piotrowska (2008).

about millet, a cereal regarded as particularly important during the earlier part of the Middle Ages (Marinval, 1992; Ruas, 1992; Austin, 2006). Additionally, as discussed in Section 2, this data needs to be interpreted with caution. If a given cereal is represented as a higher proportion of pollen grains than some other cereal in a given time period, it does not necessarily mean that the former cereal was cultivated in larger absolute volumes than the latter; such differences can be attributed to variation in the production and distribution of pollen across various types of cereals (Hellman et al., 2009). For example, rye produces at least four times as much pollen as any other cereal. Consequently, proportions of various cereals on cumulative diagrams can be seriously distorted. We may achieve some degree of visual correction by weighting our estimated proportions of each cereal type by its pollen productivity, but unfortunately there is only one study, to the best of our knowledge, which offers information on pollen productivity of all relevant cereal types, and it uses data from Uttar Pradesh in India (Agnihotri and Singh, 1975). In Table 3, we present these estimates of pollen productivity, together with additional data on the pollen productivity of rye from Germany (Pohl, 1937) and Poland (Piotrowska, 2008). We use the estimates from Agnihotri and Singh (1975) to correct inferred pollen fractions in our cumulative diagrams. These diagrams still do not provide a direct assessment of the actual structure of the agricultural output in a given time period; nevertheless, they do give a more reliable indication of these proportions and the directions in which they were changing.

With the help of these corrected cumulative diagrams we are able to present an 
interpretation of our reconstruction of regional trends in agricultural output. When necessary, diagrams with trends of single cereal types are also presented. The following discussion focuses on three periods of major economic developments in Central Europe: the dawn of the Middle Ages, the climax of medieval societies and, finally, the early modern transformation of European economies. Our main interest is in pointing out the differences between the five regions, from the East to the West. There is now no doubt that, by the end of the early modern period, major differences can be observed in the economic development between Western European countries and the rest of the continent; there was also a significant divergence within Central Europe itself (Kula, 1976; van Zanden, 2009), which can be compared to the Great Divergence between Europe and other economic systems of the world, such as China or Japan (Pomeranz, 2000; Allen, 2009). The continuous records of the agricultural output of five regional economies from Germany, Poland, and the Czech Republic enable us to reconstruct the chronology of this intra-European divergence, and to speculate about its connections with other economic processes and political transformations. However, our results do not test the 'divergence hypothesis' in a classical way, because we are unable to present any reconstructions of GDP per capita or similar measures. However, as will become visible in the following discussion, our reconstructions shed new light on the structural features of pre-industrial agrarian economies within Central Europe. Thus, by comparing the chronology and the relative scale of transformations in Greater and Lesser Poland, Bohemia, Brandenburg, and Lower Saxony, we may add new evidence to the discussion on the origins of the economic differences between various parts of Europe.

\subsection{The Beginnings of the Agrarian Economies of Central Europe}

Archaeological research leaves no doubt that Central Europe has been inhabited for several millennia and that, throughout this period, its populations gradually attained 
Figure 2: Agricultural Output in Greater Poland, 0-2000 AD

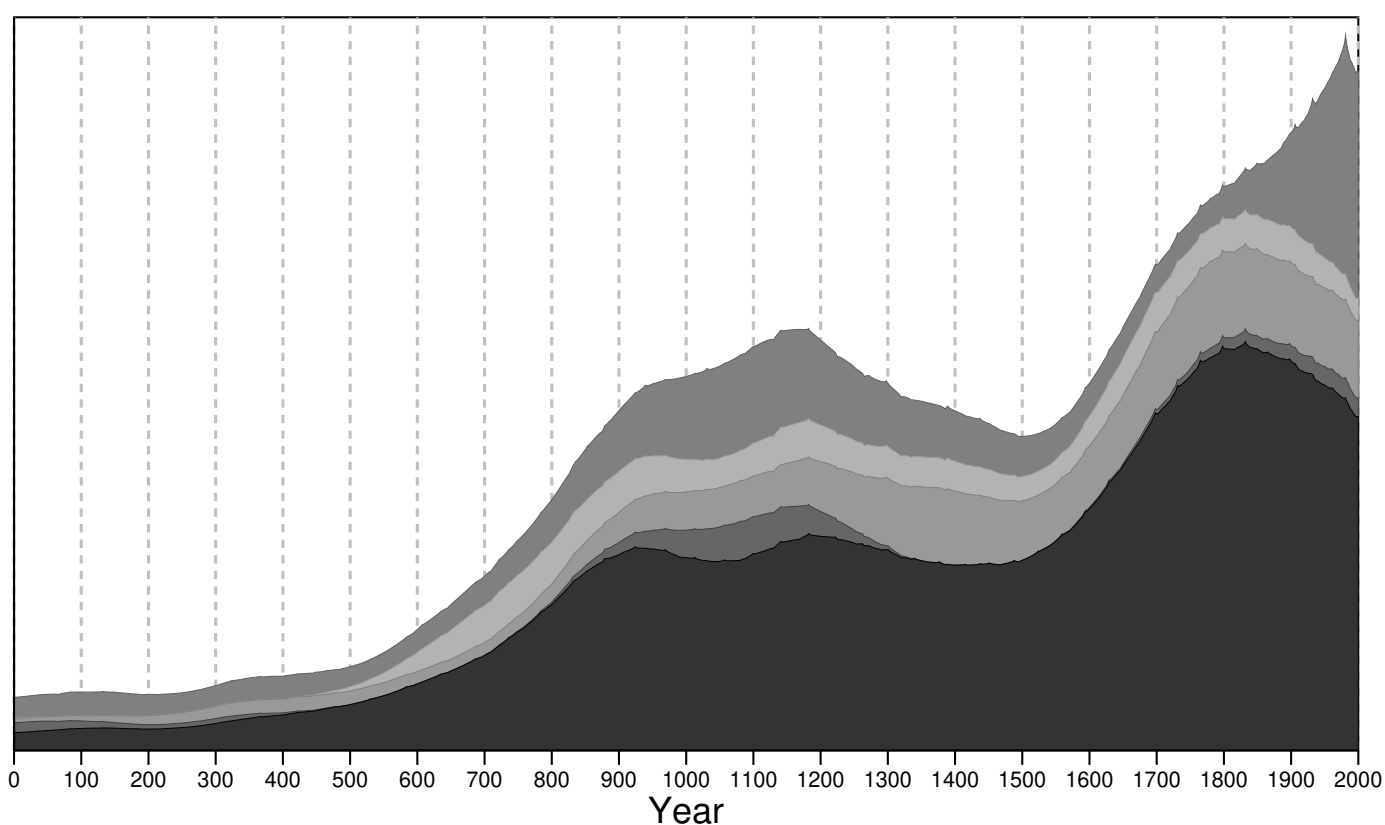

\begin{tabular}{|lll|}
\hline Wheat & Barley & Cerealia-type \\
Oats & Rye & \\
\hline
\end{tabular}

more and more complex levels of material culture and economic life. Nonetheless, it was only after the turbulent centuries of the Hunnish invasions and the disintegration of the Roman Empire (fifth-sixth century AD) that a new world began to emerge (Dembińska, 1965; Kaczanowski and Parczewski, 2005). This watershed between the earlier periods and the Central European economic landscape that continued well into the Industrial Age is also visible in our results. Our data set covers only the last two millennia, yet even the results obtained for this period show that regional agrarian economies in the first five-to-six hundred years, although characterized by some fluctuations that might be explained by archaeological information, were different in nature to the structures that appeared at the dawn of the medieval era.

Thus, on all five diagrams (Figures 2-6) it is possible to identify the moment when the 'current' agrarian economy began. ${ }^{10}$ What is striking is the fact that in all

\footnotetext{
${ }^{10}$ Note that none of these figures includes any information about how the vertical axes are scaled. This is because our data cannot be interpreted in any absolute terms, and therefore we remove these scales to avoid confusion.
} 
Figure 3: Agricultural Output in Lesser Poland, 0-2000 AD

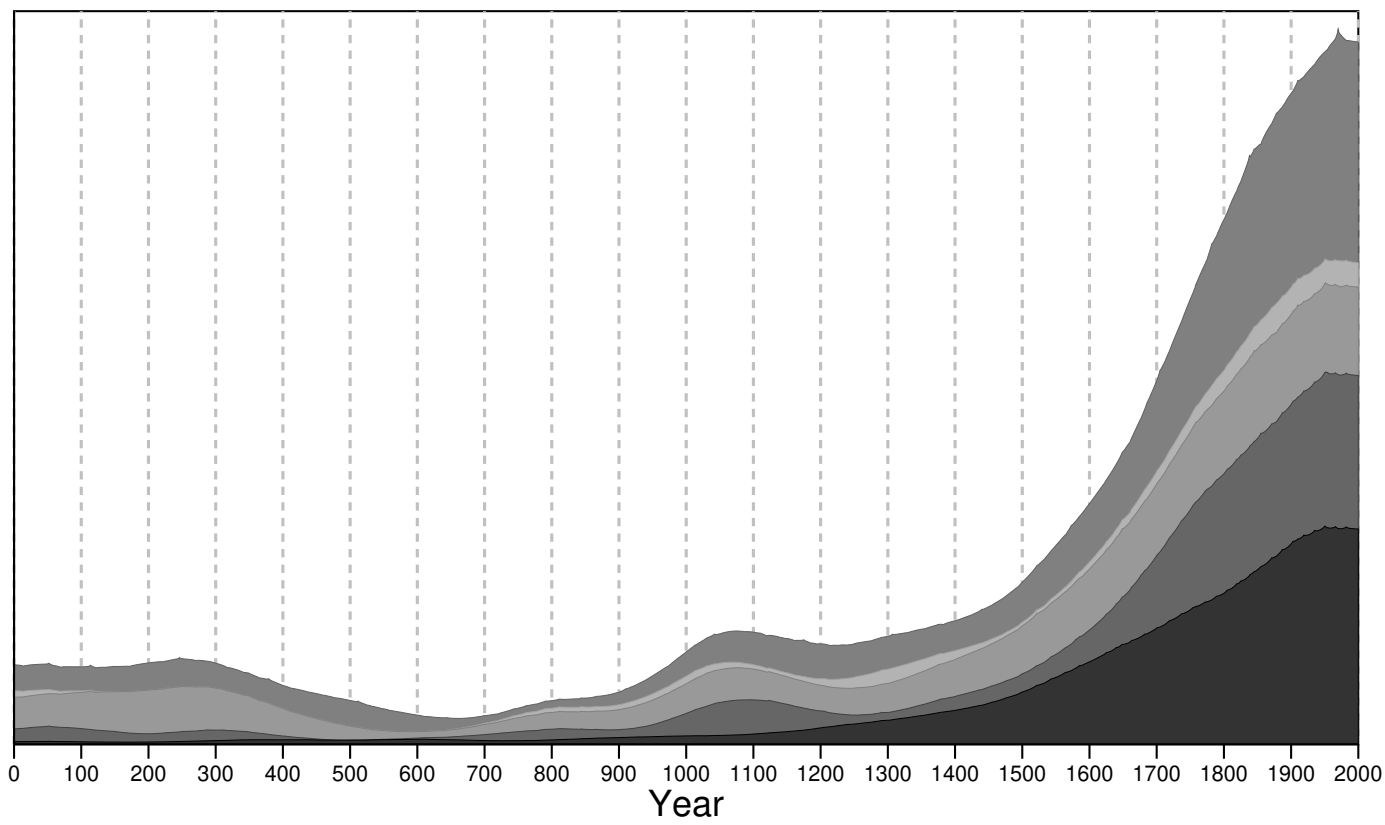

\begin{tabular}{lll} 
Wheat & Barley & Cerealia-type \\
Oats & Rye & \\
\hline
\end{tabular}

Figure 4: Agricultural Output in Bohemia, 0-2000 AD

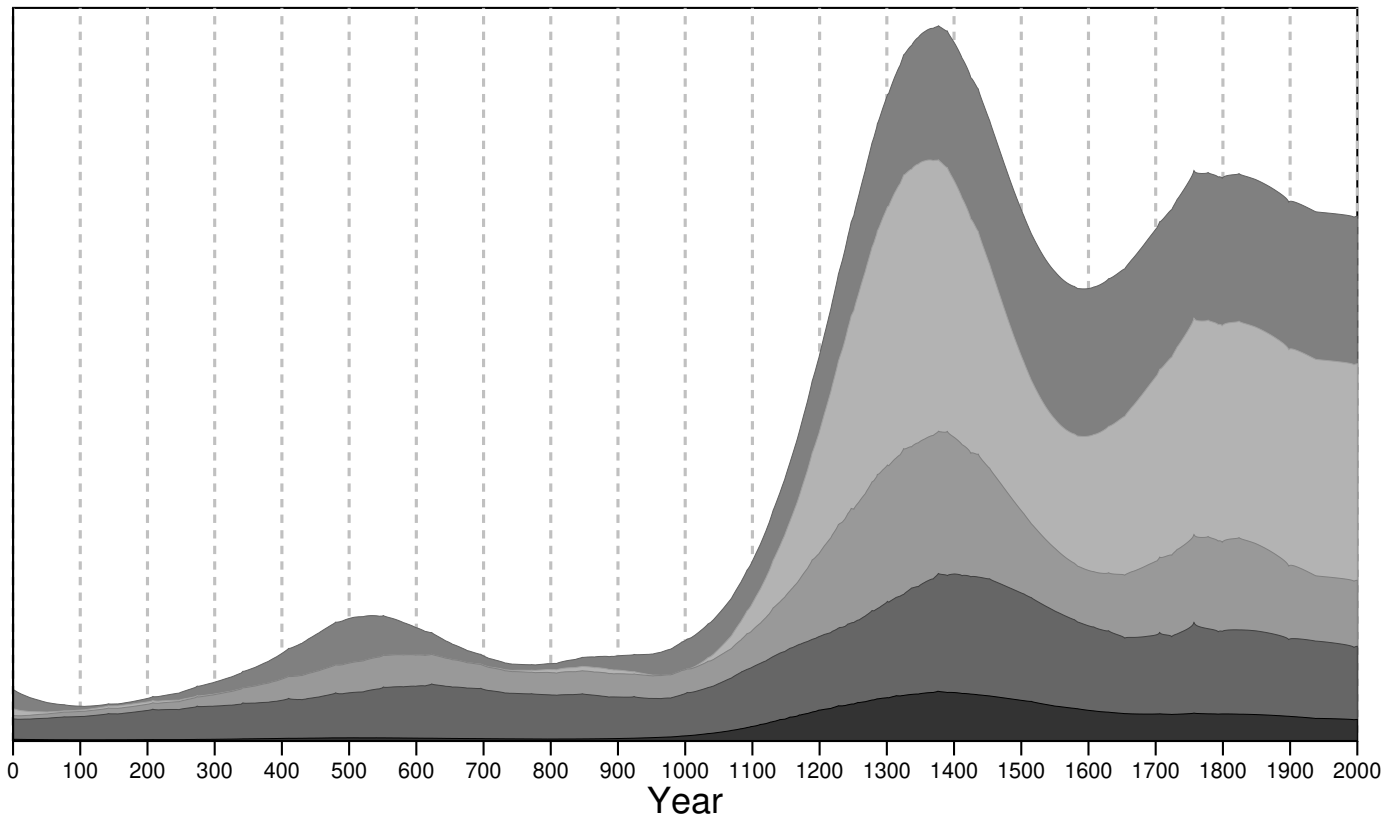

Wheat

Oats
Barley

Rye
Cerealia-type 
Figure 5: Agricultural Output in Brandenburg, 0-2000 AD

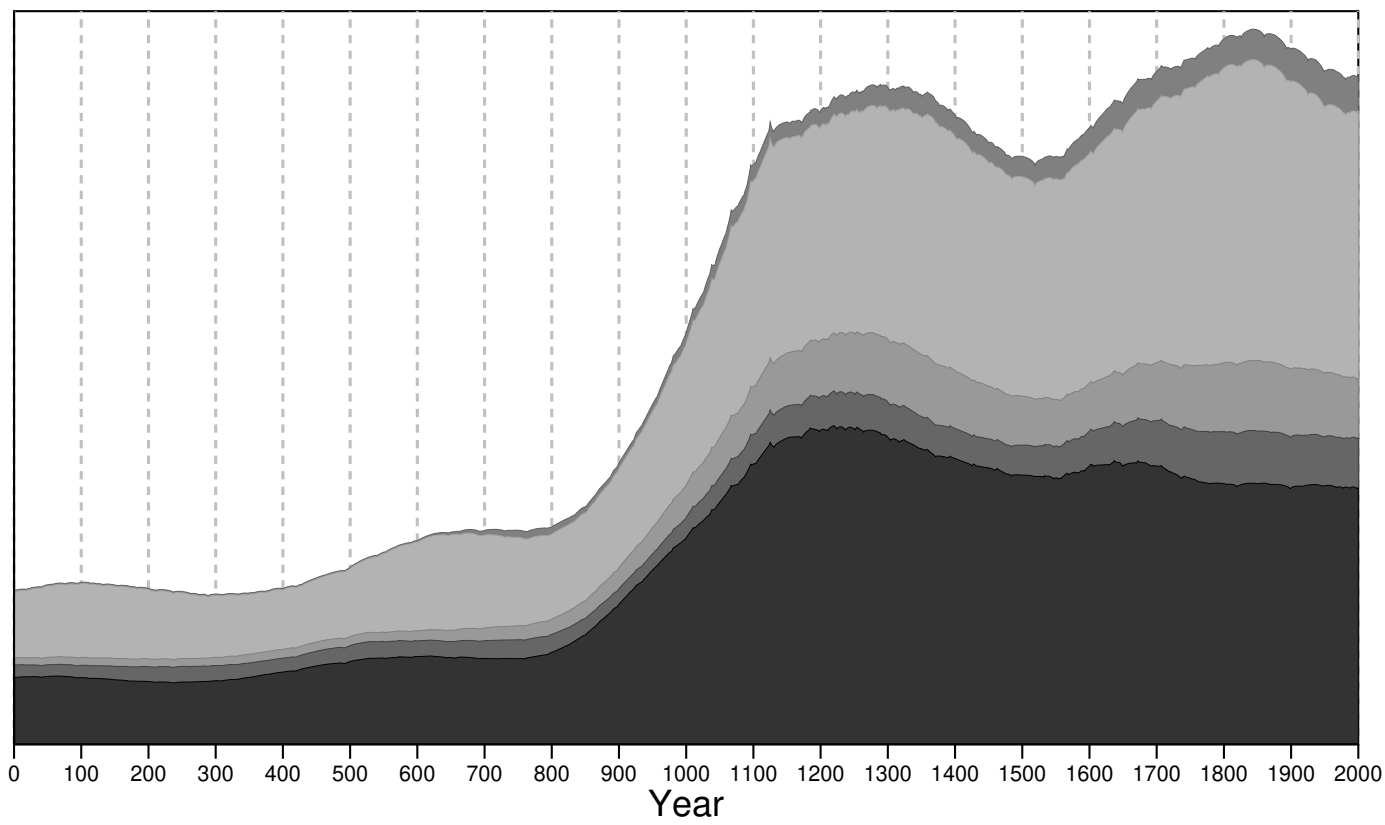

$\begin{array}{lll}\text { Wheat } & \text { Barley } & \text { Cerealia-type } \\ \text { Oats } & \text { Rye } & \end{array}$

Figure 6: Agricultural Output in Lower Saxony, 0-2000 AD

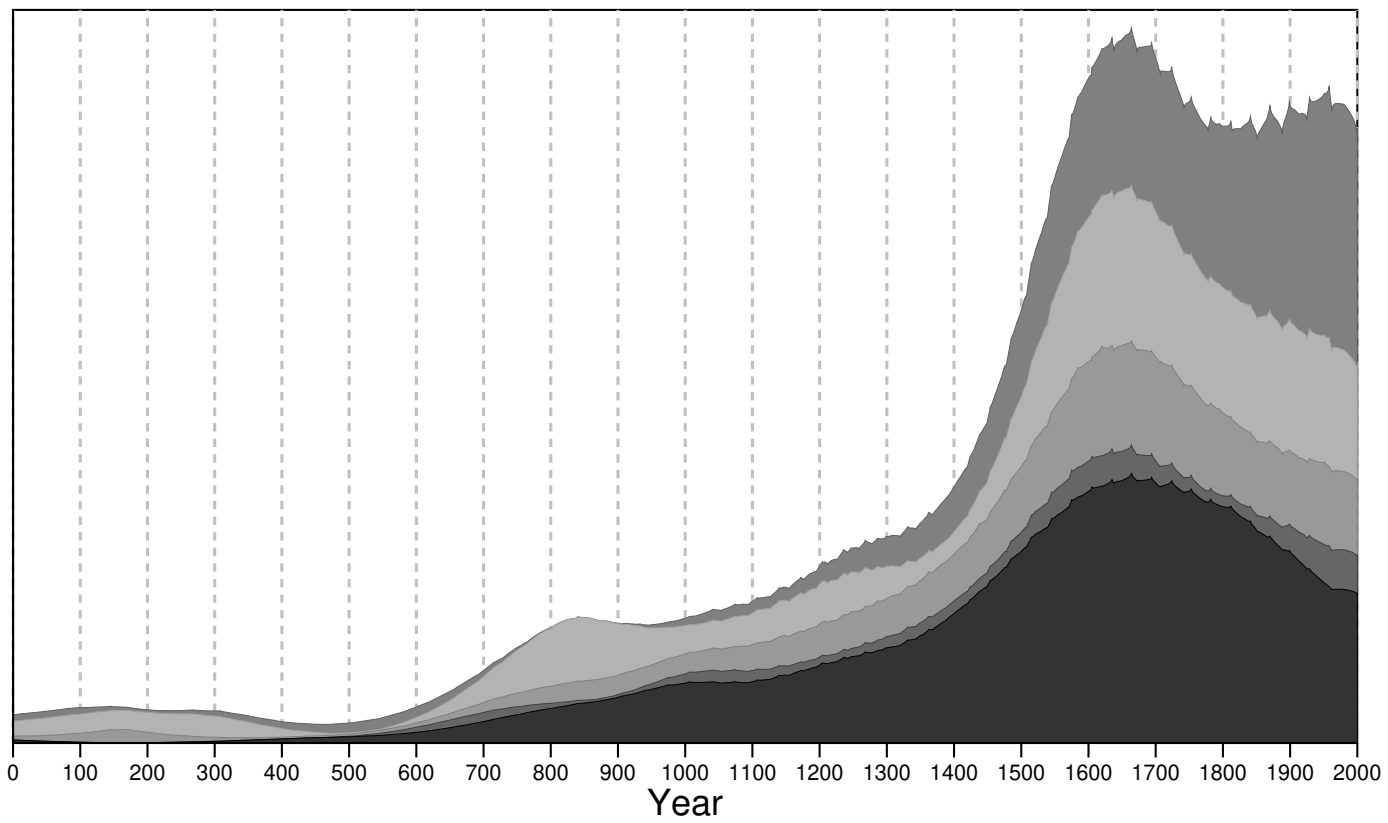

\begin{tabular}{|l|l|l|l|l}
\hline Wheat & Barley & Cerealia-type \\
Oats & Rye & \\
\hline
\end{tabular}


five regions these beginnings are different - not only in terms of their chronology, but also in terms of the scale of changes and the structure of cereal production. In Greater Poland, there is a long period of intensive growth that begins in the first decades of the sixth century AD (after 500) and continues at the same pace until the middle of the tenth century. The starting point of this trend is visible not only in the accelerated growth of the cumulative curve of cereals, but also in the appearance of a new cereal, barley. Rye was to become another very important cereal type in this period, and it remained so until the end of the early modern period. Its proportional values started rising slowly even before the sixth century, but it is from this moment onward that its expansion becomes particularly intensive. Interestingly, whereas rye seems to play a significant role in the rapid expansion of Greater Poland's agrarian economy until its stabilization in the tenth century, other cereals appear to have had specific periods of expansion. Thus, the appearance and growth of barley's share in the structure of cereals characterized the first phase of the early medieval agrarian expansion in Greater Poland, whereas wheat and oats can be considered the cereals of the second phase. The latter were introduced from the ninth century onward, which is also the period during which the values of wheat started to rise. The entire era of the accelerated early medieval growth comes to a halt in the first half of the tenth century, exactly before the Piast dynasty - based in this very region - managed to create a permanent polity that later became the Polish state (Buko, 2006). The coincidence of these events leads to two important observations. On one hand, the formation of state structures clearly followed a long period of intensive economic growth; on the other, these political processes took place exactly at the time when the region's economy experienced transition to a proper medieval form, characterized by markedly different trends.

The mountainous hinterland of Lesser Poland offers a good comparison for the pattern of growth visible in Greater Poland (intensive economic growth followed by stabilization relating to the formation of a state), as it presents a totally different 
scenario. No visible growth takes place before the tenth and eleventh centuries, and this is not surprising given both the peripheral location of the area within the early medieval political-economic networks, as well as its unattractiveness in comparison to the lowland areas of Lesser Poland that were gradually settled throughout the early medieval period (Buko, 2006). Interestingly, the structure of this relatively small agrarian economy - which seems to have developed as a result of growth in the tenth and eleventh centuries - was dominated by wheat and oats, the two cereals that started to gain in importance in Greater Poland during the second phase of early medieval expansion. Surprisingly, the key cereal of Greater Poland - rye - seems to be uncultivated in the mountains of Lesser Poland during the early Middle Ages, although it was introduced to the region a few centuries later. This late appearance of agrarian activity in the form of wheat and oat cultivation, however, is parallel to the second stage of Greater Poland's agrarian development in the early medieval era, and suggests the adoption of similar agricultural strategies by populations which came to the region after this type of agrarian economy had proved successful elsewhere.

As we move further south from Greater Poland, to Bohemia, the differences become even more striking. The medieval economy seems to start in the ninth century, with a slight growth in wheat values. Rye appears as late as the middle of the tenth century, which is also when wheat stops its increase and enters a period of stability lasting more than a century. The early tenth century is the moment when the Přemyslid dynasty formed its state in Bohemia (Matla-Kozłowska, 2008). It seems, however, that while the development of complex political structures quickly stabilized the production of wheat, it prompted the introduction of new cultivars - rye and, even more importantly, barley - that, in a short time, transformed the relatively small-scale early medieval agrarian economy based on wheat and oats.

The beginnings of the agrarian economy in Brandenburg, on the contrary, seem to have followed the scenario we have already witnessed in Greater Poland. After a slight increase in rye and barley around the sixth century - synchronous with the beginning 
of the early medieval economic expansion in Greater Poland - the crucial period of growth starts towards the end of the ninth century, and continues well into the eleventh. As in Greater Poland, the two key cereals for this period are rye and barley. Another parallel is the chronological relationship of the first agrarian expansion and the appearance of stronger political structures. Although some Slavic polities formed in this region in the tenth century, and again in the eleventh, they did not - for various reasons, including the proximity of the powerful German marches - succeed in developing lasting structures that would transform this region into the heartland of a real state (Strzelczyk, 2002). A state was only formed as late as the first half of the twelfth century, with the creation of the march of Brandenburg (Helbig, 1973; Strzelczyk, 1975), and it is exactly around 1125 AD that the rapid early medieval expansion slowed down. The phenomenon of pre-state economic growth is also visible, though much earlier, further West in Lower Saxony. Its scale is not as impressive as in the two other regions of the Middle European Plain, Brandenburg and Greater Poland; nevertheless, there is no doubt that, between the sixth and eighth centuries, a new agrarian structure developed, based - as elsewhere - on rye and barley. In this case its stabilization also seems to correlate with the introduction of complex political structures in this region, which occurred in the late eighth century when Charlemagne conquered this part of Europe (Kahl, 1982).

In four out of the five analyzed regions, the early Middle Ages were a period of substantial economic growth which laid the foundations for the agrarian economies of Central Europe. The only real exception, the mountainous hinterlands of Lesser Poland, followed a different path of economic development due to its peripheral location. One may, of course, observe important differences between the various regional scenarios. First of all, in each region the period of early medieval economic expansion can be dated to different centuries. However, in all three of the regions located on the Middle European Plain, the first sign of growth is visible in the sixth century; the final ending dates have to do with political processes, which do not seem to have 
been directly related to economic changes in the case of all three regions. Secondly, when compared with later agrarian developments, the scale of early medieval developments varies from one region to another. Most importantly, however, the early medieval economic expansion was taking place when the society had not yet formed any complex political structures. Economic growth preceded the formation of state, and the appearance of strong centers of power - either from within or from outside - coincided with some sort of stabilization: the pace of agrarian expansion slowed down and the structure of cereal production started to change.

\subsection{The Medieval Developments}

The gradual appearance of state structures in the Central European regions led to several important changes in the conditions of economic life. First, the states introduced their systems of tax extraction, often favoring one type of economic activity over another (Lübke, 1991; Modzelewski, 2000; Gawlas, 2000; Klápště, 2012). Second, regional economies became increasingly integrated into the pan-European socioeconomic system, with its flows of settlers, ideas, and goods. All of these processes are reflected in the agrarian output of our regions, and it is thus worth investigating the changing structures of cereal production, as well as the chronology and potential historical contexts of peaks and falls in both the cumulative cereal curve and individual cereals. This subsection will, therefore, explore when and how the medieval agrarian economies of Central Europe achieved their climactic point, as well as the ramifications of their late medieval crisis, if they experienced it at all.

The emergence of a state in Greater Poland did not stop the expansion of the agrarian economy. What is most characteristic for this period, however, is not the growth itself, but the continued transformation of the structure of cereal production. The tenth and eleventh centuries saw a decrease in the importance of rye, and agrarian expansion was sustained by increased production of wheat and oats. Values of rye rose slightly in the twelfth century. The climactic point is reached relatively 
early, at the end of the twelfth century, while the transformation of social and legal structures within the countryside of Greater Poland continued throughout the thirteenth century (Wyszkowski, 2009). This would suggest that the region's agrarian growth was sustained by local resources and, in particular, by its own population who cultivated new cereal fields in the agricultural land still available and, at the same time, diversified its cultivation strategies. Interestingly, there is no sign of the influence of German settlement on Greater Poland's agrarian output. This accords with the written sources which suggest that this phenomenon was not as strong in this part of Poland as it was in the south. The later Middle Ages were a period of considerable contraction, especially in the production of wheat (see Figure 7). Since the population of Greater Poland did not suffer from the Black Death, explanations of this late medieval crisis should be sought elsewhere. If one focuses more closely on the very area in which the majority of Greater Poland's pollen sites are located, one may discover that a key factor contributing to the late medieval crisis was warfare. The worst period of crisis coincides with the decades of wars between the Teutonic order and Polish kings. The eastern part of Greater Poland was very close to both Pomerania and Kuyavia, the regions in which most of the warfare took place (Biskup, 1993). The wars ended in 1466, and it was soon afterward that the period of early modern agrarian growth began.

In the southern part of Lesser Poland, the Middle Ages witnessed a slow but stable growth in the values of rye as well as a period in the twelfth-thirteenth centuries where the presence of barley increased at the expense of oats. However, these were minor developments compared to the enormous agrarian expansion that started in the fifteenth century, and accelerated during the early modern period. In comparison with the economic fluctuations in Greater Poland, the mountainous hinterlands of Lesser Poland remained a complete periphery; this situation started to change only at the very end of the Middle Ages, when large waves of new settlers arrived in the area (Podraza, 1970). 
Figure 7: Rye and Wheat in Greater Poland, 0-2000 AD

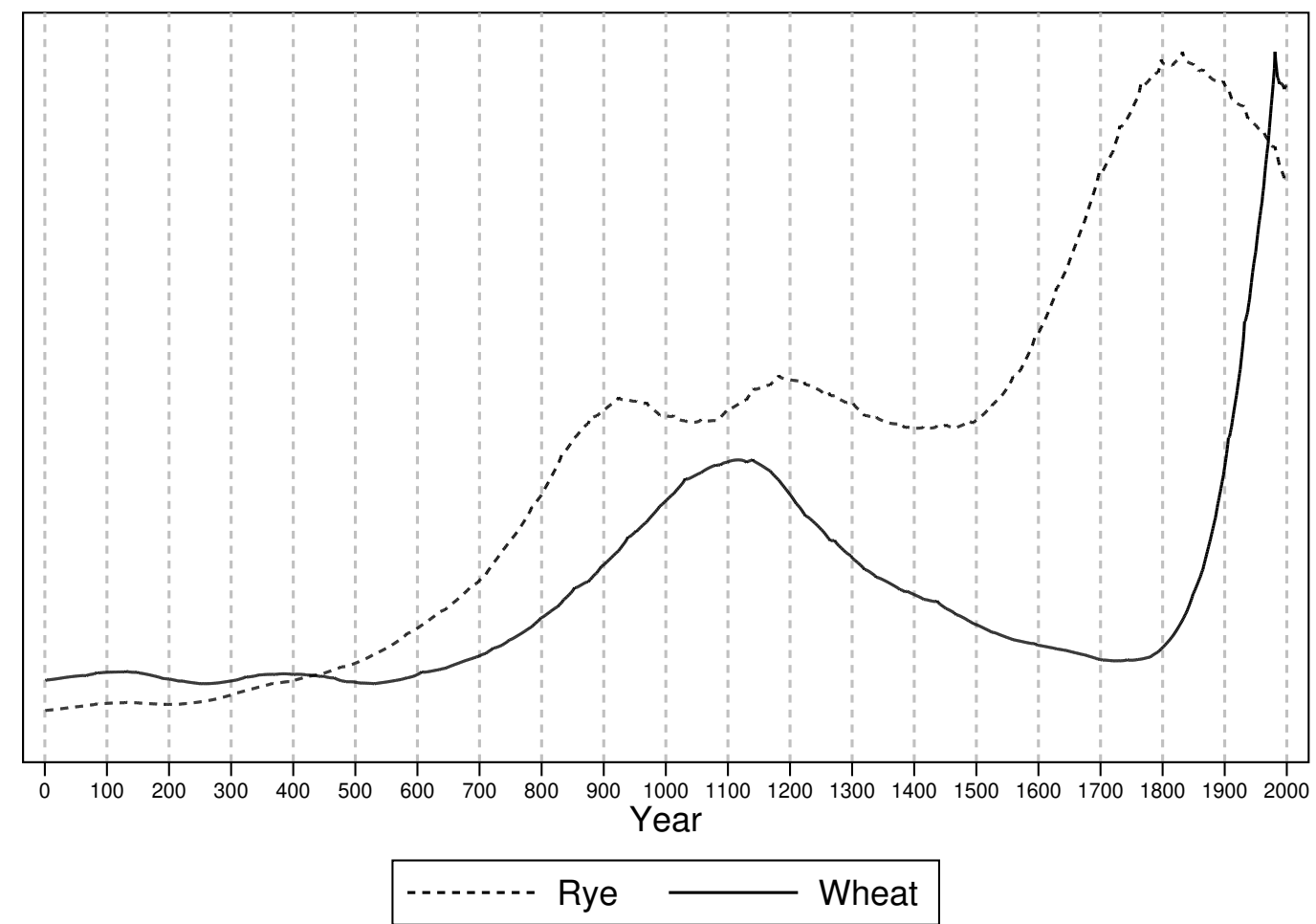

By contrast, agrarian production in the heartlands of the Czech Kingdom, located around its capital of Prague, expanded rapidly from the eleventh until the fourteenth centuries, throughout the period in which the Czech state flourished and became the leading political power in Central Europe. It is worth noting that, unlike in Greater Poland, it was barley and wheat rather than rye that played the key role in the growth of cereal production; the importance of these cereals is further confirmed by the fact that, during the same period, the Czech church collected tithe in barley and wheat (Cosmas, 1955). The crisis clearly starts with the Black Death, and is reflected by a drop in the values of barley, rye and oats. The shock of the plague in the midfourteenth century was followed, in the fifteenth century, by several decades of internal unrest caused by the Hussite wars (Šmahel, 2002). At the same time, while the overall cereal production was shrinking, its structure was gradually changing: whereas the crisis resulted in substantial drops in the values of barley, oats and rye, wheat did not experience any drop and thus its importance was steadily growing. 
Figure 8: Barley and Wheat in Bohemia, 0-2000 AD

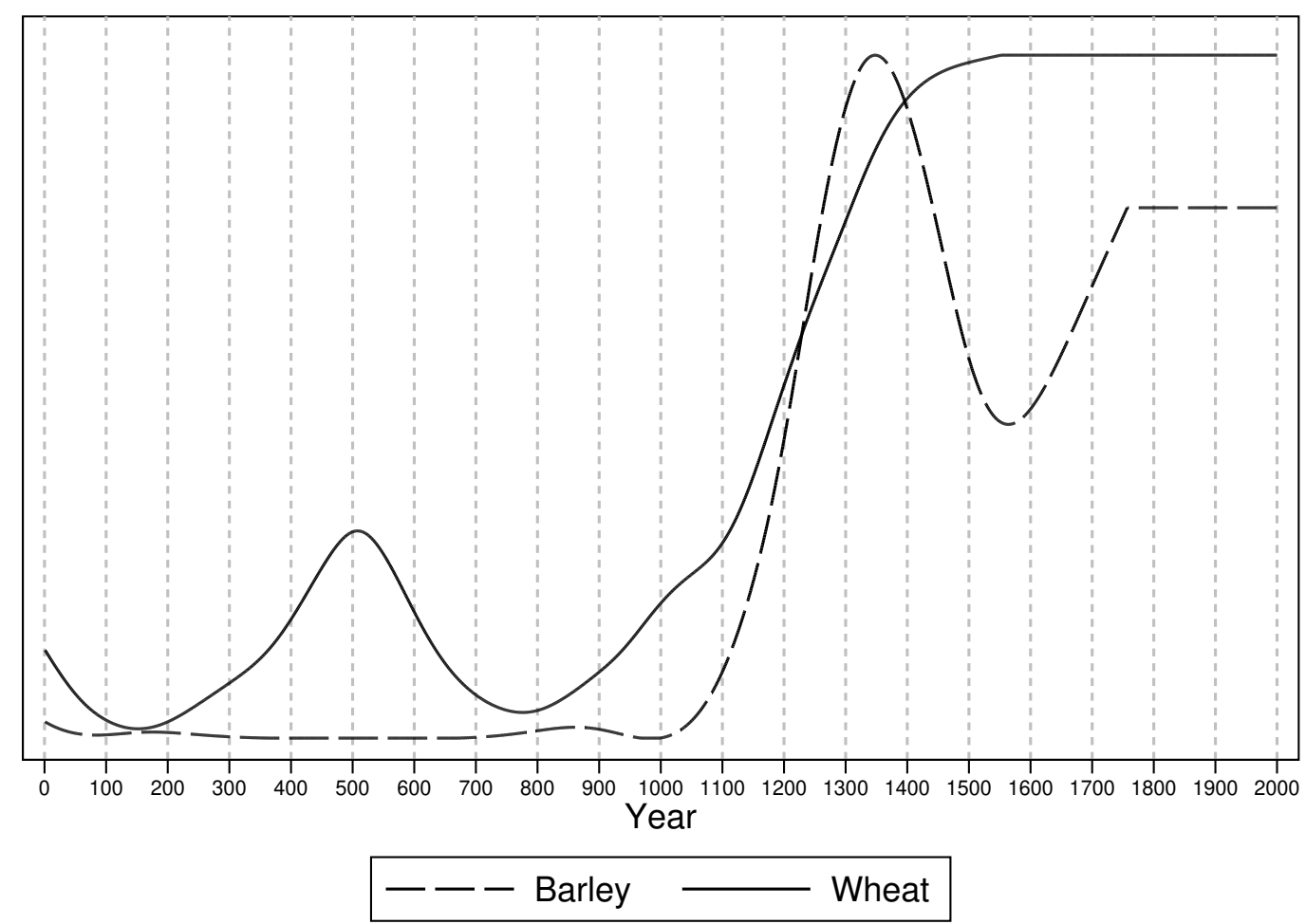

The medieval developments in Brandenburg were closer to Greater Poland's final stage of medieval growth than to the huge expansion of agriculture that was taking place in the heart of the Czech Kingdom. Agrarian growth continued after the creation of the March of Brandenburg, but on a much reduced scale. This would suggest that the landscape was substantially transformed in the preceding period, and the region's agrarian economy may have already been close to achieving the limits of its expansion. The German political institutions were thus built in a region that was already relatively well-developed in terms of its agrarian production - its society and economy were certainly not created ex nihilo. As in other areas of Central Europe, the eleventh to the thirteenth centuries were a period of important structural transformations, specifically a gradual rise in the importance of barley and wheat at the expense of rye. As in Bohemia, the crisis coincides with the Black Death. In addition to a sudden drop in the region's population, there was also a decrease in the demand for cereal production in the Netherlands, which suffered greatly from the pandemic 
Figure 9: Barley, Rye, and Wheat in Brandenburg, 0-2000 AD
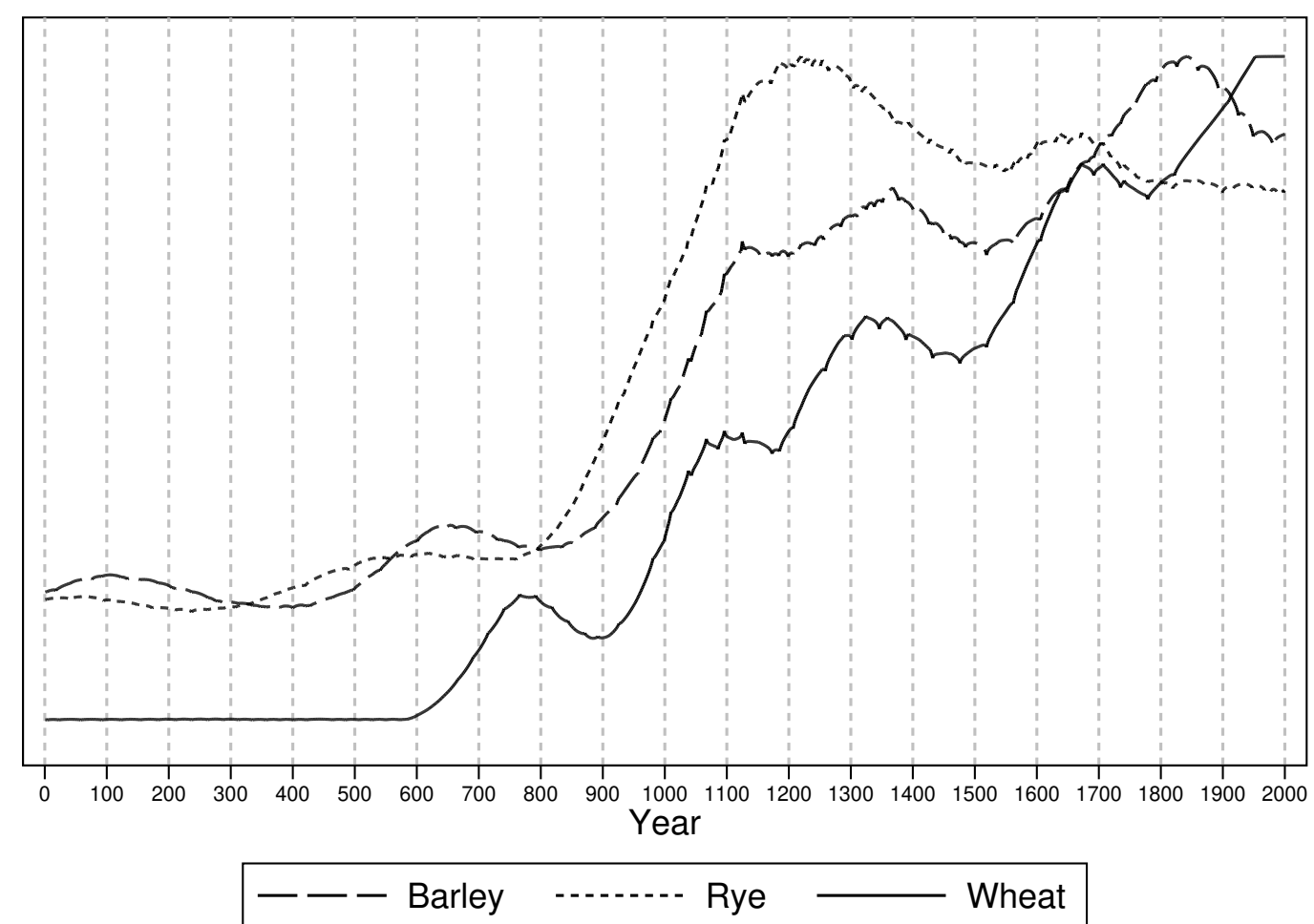

and stopped importing large amounts of grain from Central Europe for more than a century (Hoffmann, 1989).

What happened in Lower Saxony, to the west of Brandenburg, was completely different. First, there is no sign that the Black Death had any influence on cereal production, which reinforces the argument that the disappearance of the export opportunities, rather than local demographic problems, brought about the late medieval crisis in Brandenburg. Second, while one may observe sustained growth in cereal production - as well as the increased importance of wheat - between the tenth and the fourteenth centuries, the major change did not occur until the fifteenth century. It was during this time - and not a century later, as in Poland or Brandenburg - that the transition to modernity began, and this rapid growth in agrarian output lasted until the first decades of the seventeenth century.

While early medieval developments were, despite some chronological differences, roughly the same across Central Europe, the later part of the medieval period - in 
particular the last two centuries of the Middle Ages - saw the emergence of economic divergence between the regions located to the East and the West of the Elbe. Three of the regions located to the East - Greater Poland, Bohemia, and Brandenburg went through a severe late medieval crisis in agrarian production; however the data from Lower Saxony does not show any signs of crisis during the same period (if anything, the fourteenth century saw a decrease in barley). Moreover, a period of accelerated growth had already started in the West when the three other Central European economies had not even started to recover from the late medieval crisis.

\subsection{The Transition to Modernity}

The divergence between East and West grew even more pronounced in the early modern period, although all five regions experienced significant agrarian expansion in the sixteenth century. In Greater Poland, trends in agricultural production reversed after the late medieval crisis. Indeed, the second major phase in the transformation of the region's landscape - comparable to what happened in the early medieval period occurred between the sixteenth and eighteenth centuries. It was the development of an early modern manor economy, aimed at exporting grain to the Netherlands and other western markets, that brought about these changes (Kula, 1976). The importance of the export market as the key incentive for agrarian growth is evident in the structure of Greater Poland's early modern cereal production. Until the eighteenth century, rye achieves values that are incomparably higher than those of other cereals; by contrast the values of wheat actually decrease in the sixteenth and seventeenth centuries. The structure of Poland's grain export going through Gdańsk, and then the Danish customs at the strait of Sound, is exactly the same: from the beginning it was dominated by rye (Bang, 1933, 1945; Biernat, 1962; Narojczyk, 2007). Even when the volume of grain export started to decrease in the seventeenth century, the new agrarian structure was maintained and even sustained further expansion.

In Lesser Poland, the sixteenth to eighteenth centuries were the period when the 
region's mountainous hinterlands were colonized (Podraza, 1970). The enormous expansion of cereal production leaves no doubt in this respect: more and more land was used for cultivation, and the landscape of Lesser Poland was completely transformed. There are also similarities between the two Polish regions in terms of the structure of cereal production although, in Lesser Poland, rye and wheat followed synchronous paths of rapid growth, while in Greater Poland, wheat started to increase two centuries later.

In Bohemia and Brandenburg, barley was responsible for the early modern growth, while wheat retained or improved its position in comparison to other cereals. It is worth noting, however, that while the early modern growth in Brandenburg starts right at the beginning of the sixteenth century - and is thus synchronous with similar developments in Poland - in Bohemia the period of growth started a few decades later, which suggests that the region was still slowly recovering from the crisis of the Hussite wars, and perhaps suffered from political instability caused by the Turkish conquest of Hungary.

The fate of Lower Saxony was clearly different. Growth that had started in the fifteenth century stopped in the early seventeenth century, which saw a continued fall in the values of rye and barley, in addition to a stagnation in wheat production. Again, this illustrates the influence of warfare on agrarian output, as this is the period when the Thirty Years' War caused huge damage and population loss across northern Germany (Rabb, 1962). Agrarian growth reappeared in the later seventeenth century, although this time it was restricted to wheat, whose values continued to grow at least until the end of the nineteenth century.

Apart from providing new evidence and illustrating regional economic histories, our results also show the emergence of different types of divergence within Central Europe. Thus, reducing the interpretation of these agrarian developments solely to the East-West dichotomy ignores considerable differences between the four economies located to the east of the Elbe. The transformation of Poland's economy into a 
system dominated by export is clearly visible in pollen data from Greater and Lesser Poland. Agrarian transformation on such a huge scale, however, did not take place in Brandenburg or Bohemia, which is not surprising given the fact that the same export opportunities were not at work in these regions. Thus, apart from the divergence between the West (represented here only by Lower Saxony) and the East, we have another divergence - between Poland (or rather, the economic system of the PolishLithuanian Commonwealth) and the rest of Central Europe. Apart from the scale of the early modern growth, the two Polish regions also differ from Bohemia and Brandenburg in the structure of their cereal production. Whereas, in all four regions, rye was the key cereal of the Middle Ages - in particular of the first, early medieval expansion - in Bohemia and Brandenburg its values had stabilized by the late Middle Ages; in Poland, however, rye was the cereal that drove the second, early modern phase of agrarian expansion, and wheat only started gaining in importance as late as the eighteenth century. Given the fact that environmental differences do not overlap with this 'cereal divergence', explanations should be sought elsewhere than just in ecological factors.

\section{Summary}

In this paper we have introduced palynological data as an alternative "biological measure" which can serve as a useful proxy for human activity. Palynologists routinely collect and analyze data about proportions of pollen grains of various plant taxa which are preserved in the bottom sediments of various water basins. This information allows them to study local histories in the neighborhood of a given site. In this paper we have taken this approach one step further and developed new methods to aggregate this local data intro regional trends. We have then collected a large data set of 36 pollen sites in Central Europe and used our methods to investigate longterm variation in agricultural output in Greater Poland, Lesser Poland, Bohemia, Brandenburg, and Lower Saxony since the first century AD, distinguishing between 
trends in the relative presence of barley, oats, rye, and wheat.

This analysis enables us to provide an interesting historical interpretation of the economic history of Central Europe. We demonstrate how in all our regions - except for the peripheral mountainous hinterland of Lesser Poland - agrarian economies went through initial phases of medieval development in similar ways, until the formation of state structures brought about a degree of stability. In the later part of the Middle Ages, however, the first structural differences between the East and the West started to occur. While the period of rapid 'early modern' growth had already started in Lower Saxony by the fifteenth century, that same century saw the culmination of late medieval decline in agricultural output in Brandenburg, Greater Poland, and Bohemia. The early modern period saw further structural differentiation among the agrarian economies of Central Europe. In both regions located in the Polish-Lithuanian Commonwealth, Greater and Lesser Poland, large-scale agrarian expansion (primarily in rye) started in the sixteenth century and continued for the next two centuries. Bohemia and Brandenburg, although they also experienced some early modern growth, did not undergo structural transformation on a scale comparable to the processes that took place in Poland. In this way, our results prove capable of not only providing reconstructions of regional agrarian histories over the very long term, but also of tracing the agricultural origins of modern economic divergences within Central Europe. 


\section{References}

Acemoglu, D. and Zilibotti, F. (1997). Was Prometheus unbound by chance? Risk, diversification, and growth. Journal of Political Economy, 105:709-751.

Agnihotri, M. S. and Singh, B. P. (1975). Pollen production and allergenic significance of some grasses around Lucknow. Journal of Palynology, 11:151-154.

Allen, R. C. (2000). Economic structure and agricultural productivity in Europe, 1300-1800. European Review of Economic History, 4:1-26.

Allen, R. C. (2009). Agricultural productivity and rural incomes in England and the Yangtze Delta, c.1620-c.1820. Economic History Review, 62:525-550.

Anderson, J. E. (1979). A theoretical foundation for the gravity equation. American Economic Review, 69:106-116.

Anderson, J. E. and van Wincoop, E. (2003). Gravity with gravitas: A solution to the border puzzle. American Economic Review, 93:170-192.

Andrade, A., Valdeolmillos, A., and Ruiz, B. (1994). Modern pollen spectra and contemporary vegetation in the Paramera mountain range (Avila, Spain). Review of Palaeobotany and Palynology, 82:129-139.

Austin, D. F. (2006). Fox-tail millets (Setaria: Poaceae) - abandoned food in two hemispheres. Economic Botany, 60:143-158.

Austin, G., Baten, J., and van Leeuwen, B. (2012). The biological standard of living in early nineteenth-century West Africa: New anthropometric evidence for northern Ghana and Burkina Faso. Economic History Review, 65:1280-1302.

Bang, N. E. (1933). Tabeller over skibsfart og varetransport gennem Øresund 14971660. Otto Harrassowitz. 
Bang, N. E. (1945). Tabeller over skibsfart og varetransport gennem Øresund 16611783 og gennem Strebalt 1701-1748. Otto Harrassowitz.

Baten, J., Ma, D., Morgan, S., and Wang, Q. (2010). Evolution of living standards and human capital in China in the 18-20th centuries: Evidences from real wages, age-heaping, and anthropometrics. Explorations in Economic History, 47:347-359.

Baten, J. and Murray, J. E. (2000). Heights of men and women in 19th-century Bavaria: Economic, nutritional, and disease influences. Explorations in Economic History, 37:351-369.

Behre, K.-E. (1976). Pollenanalytische Untersuchungen zur Vegetations- und Siedlungsgeschichte bei Flögeln und im Ahlenmoor (Elb-Weser-Winkel). Probleme der Küstenforschung im südlichen Nordseegebiet, 11:101-118.

Behre, K.-E. (1981). The interpretation of anthropogenic indicators in pollen diagrams. Pollen et Spores, 23:225-245.

Biernat, C. (1962). Statystyka obrotu towarowego Gdańska w latach 1651-1815. Państwowe Wydawnictwo Naukowe.

Biskup, M. (1993). Wojny Polski z Zakonem Krzyżackim: 1308-1521. Marpress.

Björck, S. and Wohlfarth, B. (2001). 14C chronostratigraphic techniques in paleolimnology. In Last, W. M. and Smol, J. P., editors, Tracking Environmental Change Using Lake Sediments. Kluwer Academic Publishers.

Blaauw, M. (2010). Methods and code for 'classical' age-modelling of radiocarbon sequences. Quaternary Geochronology, 5:512-518.

Brainerd, E. (2010). Reassessing the standard of living in the Soviet Union: An analysis using archival and anthropometric data. Journal of Economic History, 70:83-117. 
Buko, A. (2006). Archeologia Polski wczesnośredniowiecznej: Odkrycia, hipotezy, interpretacje. Wydawnictwo Trio.

Břízová, E. (1999). Late Glacial and Holocene development of the vegetation in the Labe (Elbe) river flood-plain (central Bohemia, Czech Republic). Acta Palaeobotanica Suppl., 2:549-554.

Campbell, B. M. S. and Ó Gráda, C. (2011). Harvest shortfalls, grain prices, and famines in preindustrial England. Journal of Economic History, 71:859-886.

Chen, S.-H. (1988). Neue Untersuchungen über die spät- und postglaziale Vegetationsgeschichte im Gebiet zwischen Harz und Leine (BRD). Flora, 181:147-177.

Clark, G. (1991). Yields per acre in English agriculture, 1250-1860: Evidence from labour inputs. Economic History Review, 44:445-460.

Cosmas (1955). Die Chronik der Böhmen des Cosmas von Prag. Weidmannsche Verlagsbuchhandlung.

Díaz, P. M. (1994). Relations between modern pollen rain and mediterranean vegetation in Sierra Madrona (Spain). Review of Palaeobotany and Palynology, 82:113125.

Dembińska, M. (1965). Z problematyki badań nad strukturą upraw niektórych zbóż w I tysiącleciu n.e. Archeologia Polski, 10:276-304.

Dörfler, W. (1989). Pollenanalytische Untersuchungen zur Vegetations- und Siedlungsgeschichte im Süden des Landkreises Cuxhaven, Niedersachsen. Probleme der Küstenforschung im südlichen Nordseegebiet, 17:1-75.

Eastwood, W. J. (2005). Palaeoecology and eastern Mediterranean landscapes: Theoretical and practical approaches. In Haldon, J. F., editor, General Issues in the Study of Medieval Logistics: Sources, Problems and Methodologies. Brill. 
Favre, E., Escarguel, G., Suc, J.-P., Vidal, G., and Thévenod, L. (2008). A contribution to deciphering the meaning of $\mathrm{AP} / \mathrm{NAP}$ with respect to vegetation cover. Review of Palaeobotany and Palynology, 148:13-35.

Federico, G. and Malanima, P. (2004). Progress, decline, growth: Product and productivity in Italian agriculture, 1000-2000. Economic History Review, 57:437-464.

Feeser, I. and Furholt, M. (2013). Ritual and economic activity during the Neolithic in Schleswig-Holstein, northern Germany: An approach to combine archaeological and palynological evidence. Journal of Archaeological Science, forthcoming.

Fyfe, R., Roberts, N., and Woodbridge, J. (2010). A pollen-based pseudobiomisation approach to anthropogenic land-cover change. Holocene, 20:1165-1171.

Fyfe, R. M., de Beaulieu, J.-L., Binney, H., Bradshaw, R. H. W., Brewer, S., Le Flao, A., Finsinger, W., Gaillard, M.-J., Giesecke, T., Gil-Romera, G., Grimm, E. C., Huntley, B., Kunes, P., Kühl, N., Leydet, M., Lotter, A. F., Tarasov, P. E., and Tonkov, S. (2009). The European Pollen Database: Past efforts and current activities. Vegetation History and Archaeobotany, 18:417-424.

Gaillard, M.-J., Sugita, S., Bunting, M. J., Middleton, R., Broström, A., Caseldine, C., Giesecke, T., Hellman, S. E. V., Hicks, S., Hjelle, K., Langdon, C., Nielsen, A.B., Poska, A., von Stedingk, H., Veski, S., and POLLANDCAL members (2008). The use of modelling and simulation approach in reconstructing past landscapes from fossil pollen data: A review and results from the POLLANDCAL network. Vegetation History and Archaeobotany, 17:419-443.

Galor, O. and Moav, O. (2002). Natural selection and the origin of economic growth. Quarterly Journal of Economics, 117:1133-1191.

Galor, O. and Weil, D. N. (2000). Population, technology, and growth: From Malthusian stagnation to the demographic transition and beyond. American Economic Review, 90:806-828. 
Gawlas, S. (2000). O kształt zjednoczonego Królestwa: Niemieckie władztwo terytorialne a geneza społeczno-ustrojowej odrębności Polski. Wydawnictwo DiG.

Giesecke, T. (2000). Pollenanalytische und sedimentchemische Untersuchungen zur natürlichen und anthropogenen Geschichte im Schlaubetal. Sitzungsberichte der Gesellschaft Naturforschender Freunde zu Berlin, 39:89-112.

Goodfriend, M. and McDermott, J. (1995). Early development. American Economic Review, 85:116-133.

Hanley, N., Tinch, D., Angelopoulos, K., Davies, A., Barbier, E. B., and Watson, F. (2009). What drives long-run biodiversity change? New insights from combining economics, palaeoecology and environmental history. Journal of Environmental Economics and Management, 57:5-20.

Hansen, G. D. and Prescott, E. C. (2002). Malthus to Solow. American Economic Review, 92:1205-1217.

Helbig, H. (1973). Gesellschaft und Wirtschaft der Mark Brandenburg im Mittelalter. Walter de Gruyter.

Hellman, S., Bunting, M. J., and Gaillard, M.-J. (2009). Relevant Source Area of Pollen in patchy cultural landscapes and signals of anthropogenic landscape disturbance in the pollen record: A simulation approach. Review of Palaeobotany and Palynology, 153:245-258.

Hellman, S., Gaillard, M.-J., Broström, A., and Sugita, S. (2008). The REVEALS model, a new tool to estimate past regional plant abundance from pollen data in large lakes: Validation in southern Sweden. Journal of Quaternary Science, $23: 21-42$.

Hodrick, R. J. and Prescott, E. C. (1997). Postwar U.S. business cycles: An empirical investigation. Journal of Money, Credit, and Banking, 29:1-16. 
Hoffmann, R. C. (1989). Land, Liberties, and Lordship in a Late Medieval Countryside: Agrarian Structures and Change in the Duchy of Wrockaw. University of Pennsylvania Press.

Izdebski, A. (2013). A Rural Economy in Transition: Asia Minor from Late Antiquity into the Early Middle Ages. Taubenschlag Foundation.

Izdebski, A., Koloch, G., Słoczyński, T., and Tycner-Wolicka, M. (2014). Przemiany strukturalne w gospodarce Polski i Europy Środkowej w epoce przednowoczesnej - analiza danych palinologicznych. Unpublished.

Jahns, S. (1999a). Ein holozänes Pollendiagramm vom Kleinen Mochowsee, nördliche Niederlausitz. Gleditschia, 27:45-56.

Jahns, S. (1999b). Pollenanalytische Untersuchungen am Großen Krebssee, Ostbrandenburg: Ein Beitrag zur Siedlungs- und Vegetationsgeschichte der Neuenhagener Oderinsel. Germania, 77:637-659.

Jahns, S. (2000). Late-glacial and Holocene woodland dynamics and land-use history of the Lower Oder valley, north-eastern Germany, based on two, AMS14C-dated, pollen profiles. Vegetation History and Archaeobotany, 9:111-123.

Jahns, S. (2006). The later Holocene history of vegetation, land-use and settlements around the Ahlequellmoor in the Solling area, Germany. Vegetation History and Archaeobotany, 15:57-63.

Jahns, S. (2007). Palynological investigations into the Late Pleistocene and Holocene history of vegetation and settlement at the Löddigsee, Mecklenburg, Germany. Vegetation History and Archaeobotany, 16:157-169.

Kaczanowski, P. and Parczewski, M., editors (2005). Archeologia o poczatkach Słowian: Materiaty z konferencji, Kraków, 19-21 listopada 2001. Księgarnia Akademicka. 
Kahl, H.-D. (1982). Karl der Große und die Sachsen: Stufe und Motive einer historischen "Eskalation". In Ludat, H. and Schwinges, R. C., editors, Politik, Gesellschaft, Geschichtsschreibung: Giessener Festgabe für František Graus zum 60. Geburtstag. Böhlau.

Kelly, M. (2001). Linkages, thresholds, and development. Journal of Economic Growth, 6:39-53.

Kelly, M. and Ó Gráda, C. (2013). Numerare est errare: Agricultural output and food supply in England before and during the Industrial Revolution. Journal of Economic History, 73:1132-1163.

Kögel, T. and Prskawetz, A. (2001). Agricultural productivity growth and escape from the Malthusian trap. Journal of Economic Growth, 6:337-357.

Kühl, N. (1998). Pollenanalytische Untersuchungen zur Vegetations- und Siedlungsgeschichte in einem Kesselmoor bei Drangstedt, Ldkr. Cuxhaven. Probleme der Küstenforschung im südlichen Nordseegebiet, 25:303-324.

Klápště, J. (2012). The Czech Lands in Medieval Transformation. Brill.

Kołaczek, P., Fiałkiewicz-Kozieł, B., Karpińska-Kołaczek, M., and Gałka, M. (2010). The last two millennia of vegetation development and human activity in the OrawaNowy Targ Basin (south-eastern Poland). Acta Palaeobotanica, 50:133-148.

Koepke, N. and Baten, J. (2005). The biological standard of living in Europe during the last two millennia. European Review of Economic History, 9:61-95.

Koepke, N. and Baten, J. (2008). Agricultural specialization and height in ancient and medieval Europe. Explorations in Economic History, 45:127-146.

Komlos, J. (2007). Anthropometric evidence on economic growth, biological wellbeing and regional convergence in the Habsburg Monarchy, c. 1850-1910. Cliometrica, 1:211-237. 
Komlos, J., Hau, M., and Bourguinat, N. (2003). An anthropometric history of early-modern France. European Review of Economic History, 7:159-189.

Kula, W. (1976). An Economic Theory of the Feudal System: Towards a Model of the Polish Economy, 1500-1800. N.L.B.

Kuneš, P., Abrahám, V., Kovářík, O., Kopecký, M., Břízová, E., Dudová, L., Jankovská, V., Knipping, M., Kozáková, R., Nováková, K., Petr, L., Pokorný, P., Roszková, A., Rybníčková, E., Svobodová-Svitavská, H., and Wacnik, A. (2009). Czech Quaternary Palynological Database - PALYCZ: Review and basic statistics of the data. Preslia, 81:209-238.

Lagerlöf, N.-P. (2003). From Malthus to modern growth: Can epidemics explain the three regimes? International Economic Review, 44:755-777.

Lübke, C. (1991). Arbeit und Wirtschaft im östlichen Mitteleuropa: Die Spezialisierung menschlicher Tätigkeit im Spiegel der hochmittelalterlichen Toponymie in den Herrschaftsgebieten von Piasten, Premysliden und Arpaden. Franz Steiner Verlag.

Šmahel, F. (2002). Die Hussitische Revolution. Hahnsche Buchhandlung.

Makohonienko, M. (1991). Materiały do postglacjalnej historii roślinności okolic Lednicy. Część II: Badania palinologiczne osadów Jeziora Lednickiego - rdzeń I/86 i Wal/87. In Tobolski, K., editor, Wstęp do paleoekologii Lednickiego Parku Krajobrazowego. Wydawnictwo Naukowe Uniwersytetu im. Adama Mickiewicza.

Makohonienko, M. (2000). Przyrodnicza historia Gniezna. Homini.

Marinval, P. (1992). Archaeobotanical data on millets (Panicum miliaceum and Setaria italica) in France. Review of Palaeobotany and Palynology, 73:259-270.

Matla-Kozłowska, M. (2008). Pierwsi Przemyślidzi i ich państwo (od X do połowy 
XI wieku): Eskpansja terytorialna i jej polityczne uwarunkowania. Wydawnictwo Poznańskie.

Milecka, K. (1998). Historia działalności człowieka w okolicach Giecza i Wagowa w świetle analizy pyłkowej. In Tobolski, K., editor, Biblioteka Studiów Lednickich, volume 3. Muzeum Pierwszych Piastów na Lednicy.

Modzelewski, K. (2000). Organizacja gospodarcza państwa piastowskiego: X-XIII wiek. Wydawnictwo Poznańskiego Towarzystwa Przyjaciół Nauk.

Narojczyk, K. (2007). Żegluga i handel battycki w świetle Tabel Cła Sundzkiego (15571783): Studium źródłoznawcze. Polskie Towarzystwo Historyczne.

Obidowicz, A. (1990). Eine pollennanalytische und moorkundliche Studie zur Vegetationsgeschichte des Podhale-Gebietes (West-Karpaten). Acta Palaeobotanica, $30: 147-219$.

O’Brien, P. K. and Prados de la Escosura, L. (1992). Agricultural productivity and European industrialization, 1890-1980. Economic History Review, 45:514-536.

Olmstead, A. L. and Rhode, P. W. (2002). The Red Queen and the Hard Reds: Productivity growth in American wheat, 1800-1940. Journal of Economic History, 62:929-966.

Piotrowska, K. (2008). Pollen production in selected species of anemophilous plants. Acta Agrobotanica, 61:41-52.

Podraza, A. (1970). Rola gospodarcza Małopolski w okresie od XVI do XVIII wieku. In Bobińska, C., editor, Kraków i Małopolska przez dzieje: Studia i szkice profesorów Uniwersytetu Jagiellońskiego. Wydawnictwo Literackie.

Pohl, F. (1937). Die Pollenerzeugung der Windblüter. Beihefte zum Botanischen Centralblatt, 56A:365-470. 
Pokorný, P. (2005). Role of man in the development of Holocene vegetation in Central Bohemia. Preslia, 77:113-128.

Pokorný, P. (2011). Neklidné časy: Kapitoly ze společných dějin přírody a lidí. Dokořán.

Pokorný, P., Klimešová, J., and Klimeš, L. (2000). Late Holocene history and vegetation dynamics of a floodplain alder carr: A case study from eastern Bohemia, Czech Republic. Folia Geobotanica, 35:43-58.

Pokorný, P. and van der Knaap, W. O. (2011). 15. Brve (Czech Republic): Vegetation development over the last about 2.5 millennia in the Bohemian Lowland close to Prague. Grana, 50:311-313.

Pomeranz, K. (2000). The Great Divergence: Europe, China, and the Making of the Modern World Economy. Princeton University Press.

Rabb, T. K. (1962). The effects of the Thirty Years' War on the German economy. Journal of Modern History, 34:40-51.

Ralska-Jasiewiczowa, M. (1980). Late-Glacial and Holocene Vegetation of the Bieszczady Mts. (Polish Eastern Carpathians). Państwowe Wydawnictwo Naukowe.

Ralska-Jasiewiczowa, M. (1983). Isopollen maps for Poland: 0-11000 years B.P. New Phytologist, 94:133-175.

Ralska-Jasiewiczowa, M., Goslar, T., Madeyska, T., and Starkel, L., editors (1998). Lake Gością̇, Central Poland: A Monographic Study. W. Szafer Institute of Botany. Polish Academy of Sciences.

Ralska-Jasiewiczowa, M., Latałowa, M., Wasylikowa, K., Tobolski, K., Madeyska, E., Wright, H. E., and Turner, C., editors (2004). Late Glacial and Holocene History 
of Vegetation in Poland Based on Isopollen Maps. W. Szafer Institute of Botany. Polish Academy of Sciences.

Reimer, P. J., Baillie, M. G. L., Bard, E., Bayliss, A., Beck, J. W., Blackwell, P. G., Bronk Ramsey, C., Buck, C. E., Burr, G. S., Edwards, R. L., Friedrich, M., Grootes, P. M., Guilderson, T. P., Hajdas, I., Heaton, T. J., Hogg, A. G., Hughen, K. A., Kaiser, K. F., Kromer, B., McCormac, F. G., Manning, S. W., Reimer, R. W., Richards, D. A., Southon, J. R., Talamo, S., Turney, C. S. M., van der Plicht, J., and Weyhenmeyer, C. E. (2009). IntCal09 and Marine09 radiocarbon age calibration curves, 0-50,000 years cal BP. Radiocarbon, 51:1111-1150.

Ruas, M.-P. (1992). The archaeobotanical record of cultivated and collected plants of economic importance from medieval sites in France. Review of Palaeobotany and Palynology, 73:301-314.

Rybníček, K. and Rybníčková, E. (1985). A palaeoecological reconstruction of precultural vegetation in the intermontane basins of the Western Carpathians. Ecologia Mediterranea, 11:27-31.

Steckel, R. H. (2003). What can be learned from skeletons that might interest economists, historians, and other social scientists? American Economic Review: Papers and Proceedings, 93:213-220.

Steckel, R. H. (2008). Biological measures of the standard of living. Journal of Economic Perspectives, 22:129-152.

Steckel, R. H. (2013). Biological measures of economic history. Annual Review of Economics, 5:401-423.

Strzelczyk, J. (1975). Brandenburgia. Książka i Wiedza.

Strzelczyk, J. (2002). Stowianie połabscy. Wydawnictwo Poznańskie. 
Sugita, S. (1993). A model of pollen source area for an entire lake surface. Quaternary Research, 39:239-244.

Szczepanek, K. (1987). Late-Glacial and Holocene pollen diagrams from Jasiel in the Low Beskid Mts. (The Carpathians). Acta Palaeobotanica, 27:9-26.

Szczepanek, K. (2001). Anthropogenic vegetation changes in the region of the Dukla Pass, the Lower Beskid Mountains. In Machnik, J., editor, Archaeology and Natural Background of the Lower Beskid Mountains. Polska Akademia Umiejętności.

Tobolski, K. (1990). Paläoökologische Untersuchungen des Siedlungsgebietes im Lednica Landschaftspark (Nordwestpolen). Offa, 47:109-131.

Tobolski, K. (1991). Dotychczasowy stan badań paleobotanicznych i biostratygraficznych Lednickiego Parku Krajobrazowego. In Tobolski, K., editor, Wstęp do paleoekologii Lednickiego Parku Krajobrazowego. Wydawnictwo Naukowe Uniwersytetu im. Adama Mickiewicza.

van Zanden, J. L. (2009). The Long Road to the Industrial Revolution: The European Economy in a Global Perspective, 1000-1800. Brill.

Vermoere, M. (2004). Holocene Vegetation History in the Territory of Sagalassos (Southwest Turkey): A Palynological Approach. Brepols.

Vermoere, M., Vanhecke, L., Waelkens, M., and Smets, E. (2001). Modern pollen studies in the territory of Sagalassos (Southwest Turkey) and their use in the interpretation of a Late Holocene pollen diagram. Review of Palaeobotany and Palynology, 114:29-56.

Voth, H.-J. and Leunig, T. (1996). Did smallpox reduce height? Stature and the standard of living in London, 1770-1873. Economic History Review, 49:541-560.

Wacnik, A. (1995). The vegetational history of local flora and evidences of human 
activities recorded in the pollen diagram from side Regetovka, NE Slovakia. Acta Palaeobotanica, 35:253-274.

Webb, T. (1974). Corresponding patterns of pollen and vegetation in lower Michigan: A comparison of quantitative data. Ecology, 55:17-28.

Willutzki, H. (1962). Zur Waldgeschichte und Vermoorung sowie über Rekurrenzflächen im Oberharz. Nova Acta Leopoldina, 25:1-52.

Wolters, S. (1999). Spät- und postglaziale Vegetationsentwicklung im Bereich der Fercher Berge südwestlich von Potsdam. Gleditschia, 27:25-44.

Wyszkowski, M. (2009). Ustrój polityczny Wielkopolski w latach 1138-1296. Wydawnictwo Poznańskie. 